\title{
Relating pollen representation to an evolving Amazonian landscape between the last glacial maximum and late Holocene
}

Article

Accepted Version

Smith, R. J., Mayle, F. E. ORCID: https://orcid.org/0000-00019208-0519, Maezumi, S. Y. and Power, M. J. (2021) Relating pollen representation to an evolving Amazonian landscape between the last glacial maximum and late Holocene.

Quaternary Research, 99. pp. 63-79. ISSN 1096-0287 doi: https://doi.org/10.1017/qua.2020.64 Available at https://centaur.reading.ac.uk/91528/

It is advisable to refer to the publisher's version if you intend to cite from the work. See Guidance on citing.

To link to this article DOI: http://dx.doi.org/10.1017/qua.2020.64

Publisher: Cambridge University Press

All outputs in CentAUR are protected by Intellectual Property Rights law, including copyright law. Copyright and IPR is retained by the creators or other copyright holders. Terms and conditions for use of this material are defined in the End User Agreement. 


\section{www.reading.ac.uk/centaur}

\section{CentAUR}

Central Archive at the University of Reading

Reading's research outputs online 


\section{Relating pollen representation to an evolving Amazonian landscape}

2 between the last glacial maximum and Late Holocene

3

4 Authors: Richard J. Smith ${ }^{\mathrm{a} 1}$, Francis E. Mayle ${ }^{\mathrm{a}}$, S. Yoshi Maezumi ${ }^{\mathrm{b}, \mathrm{c}}$, Mitchell J. Power ${ }^{\mathrm{d}}$ 5

6 Affiliations:

7 a University of Reading, Centre for Past Climate Change and Department of Geography \& 8 Environmental Science, School of Archaeology, Geography and Environmental Science 9 (SAGES), Whiteknights, PO Box 227, Reading RG6 6AB, UK 10

11 b University of Exeter, Department of Archaeology, College of Humanities, Laver Building,

12 North Park Road, Exeter EX4 4QE, UK

13

$14{ }^{\mathrm{C}}$ Department of Geography and Geology, The University of the West Indies Mona,

15 Jamaica, JM

16

17 d University of Utah, Natural History Museum of Utah, Department of Geography, Salt Lake 18 City, UT 84112, USA

19

$20 \quad{ }^{1}$ Correspondence to: f.mayle@reading.ac.uk 


\section{ABSTRACT}

22 In contrast to temperate regions, relationships between basin characteristics (e.g. type/size) 23 and fossil pollen archives have received little attention in Amazonia. Here, we compare fossil 24 pollen records of a small palm swamp (Cuatro Vientos; CV) and a nearby large lake (Laguna 25 Chaplin; LCH) in Bolivian Amazonia, demonstrating that palm swamps can yield Quaternary 26 pollen archives recording the history of terrestrial vegetation beyond the basin margin, rather 27 than merely a history of localized swamp vegetation dynamics. The pollen assemblages from 28 these two contrasting basins display remarkable agreement throughout their late Quaternary 29 history, indicating past drier climates supported savanna landscape during the last glacial 30 maximum (LGM; 24,000-18,000 cal yr BP) and savanna/semi-deciduous forest mosaic during 31 the middle Holocene (7000-4750 cal yr BP) at both regional (inferred from LCH) and local 32 (inferred from CV) spatial scales. Additionally, the local-scale catchment of CV and the basin's 33 proximity to the riverine forests of the Río Paraguá enables exploration of the extent of 34 gallery/riverine forests during the LGM and middle Holocene. We show that, between 24,000$354000 \mathrm{cal}$ yr BP, riverine/gallery rainforests were substantially reduced compared with present, 36 challenging the hypothesis that gallery rainforests were important refugia for rainforest species 37 during the drier LGM and middle Holocene.

\section{KEYWORDS}

40 Paleoecology, Quaternary, Pollen, Bolivian Amazonia, Palm Swamp, last glacial maximum, 41 Holocene 
44 The role of paleoecology in determining how Amazonian ecosystems responded to long-term past climate change is of paramount importance, given its relevance for understanding the fate of Amazonia under future climate change. Particular focus should be given to ecotonal regions of Amazonia, where humid evergreen forests form boundaries with, or grade into, savannas and/or semi-deciduous tropical dry forests. Rainforest taxa at these ecotones exist near to their climatic limits and should therefore be highly sensitive to climate change. Existing paleoecological records have demonstrated this vulnerability, with evidence for climateinduced expansion of savanna and/or dry forests during the last glacial maximum (LGM) and the middle Holocene in ecotonal eastern Amazonia (e.g. Absy et al., 1991; Hermanowski et al., 2012; Fontes et al., 2017; Reis et al., 2017) and southern Amazonia (Mayle et al., 2000; Burbridge et al., 2004; Carson et al., 2014). However, the paucity of these paleo-records means that considerable uncertainty exists as to the full nature and extent of these biome shifts.

Unfortunately, finding suitable paleoecological sites is often a challenge in this region. The dynamic hydrology of Amazonia means that long-lived, permanent lake basins are uncommon (Colinvaux et al., 1985; Latrubesse, 2012). Small oxbow lakes are widespread, but they rarely have sediment records that span the multi-millennial timescales needed to capture long-term climate change (Toivonen et al., 2007; Latrubesse, 2012; Rodriguez-Zorro et al., 2015).

In the absence of suitable lake sediment records, bogs and palm swamps are often targeted for paleoecological analysis. However, their value is often called into question due to uncertainty over whether their pollen archives reliably capture the history of local terrestrial vegetation beyond the bog/swamp, or instead merely reveal the history of swamp/bog vegetation growing within the basin itself. In the latter case, they are of little use for paleoecologists seeking to understand Holocene/Quaternary forest dynamics. Such concerns are borne out by pollen records from sites such as the Pantano de Monica palm swamp in the central Colombian Amazon (Behling et al., 1999) and the Vereda de Águas Emendadas palm swamp in central Brazil (Barberi et al., 2000), both of which are dominated by swamp taxa (e.g. palms and sedges) through much of the Holocene. Furthermore, because key pollen taxa such as grass and sedge can only be identified to family level (Poaceae and Cyperaceae, respectively), it is often unclear whether their presence signifies semi-aquatic species growing within the swamp (e.g. floating sedge mat) or instead open, seasonally-flooded savanna beyond the swamp. 
Here, we present the results of a natural experiment, whereby analysis of fossil pollen records from a small palm swamp and an adjacent large lake provides a rare opportunity to determine the potential for palm swamps to reliably record glacial-Holocene terrestrial vegetation histories, or merely a history of swamp vegetation. We present a 24,000-yr fossil pollen record from Cuatro Vientos palm swamp located in Noel Kempff Mercado National Park (NKMNP), north-eastern Bolivia (southern Amazonian forest-savanna ecotone) (Figs. 1 and 2). The current state of knowledge of the late Quaternary paleoecology of this region is predominantly based on the pollen records from two large lakes: Lagunas Bella Vista and Chaplin (Mayle et al., 2000; Burbridge et al. 2004) (Figs. 1 and 2). These records demonstrate that most of the regional catchments of these two lakes, which are today dominated by humid evergreen rainforest, were previously characterized by a mosaic of savanna and semi-deciduous dry forest communities during the LGM and early/middle Holocene under drier-than-present climatic conditions. The regional climate became gradually wetter through the late Holocene, causing the progressive replacement of savanna and dry forest by humid evergreen rainforest, which expanded in the northern part of NKMNP 3000 cal yr BP (around Laguna Bella Vista) and attained current levels in the south of the park (around Laguna Chaplin) by $\sim 750 \mathrm{cal}$ yr BP (Mayle et al. 2000; Burbridge et al. 2004).

Cuatro Vientos (CV) palm swamp is located only $6.5 \mathrm{~km}$ from Laguna Chaplin (Fig. 2), and thus presents a unique opportunity to directly compare the paleoecological record of a palm swamp with that of a neighboring large lake ( $25 \mathrm{~km}^{2}$ basin). Given the close proximity of these two sites, located within the same vegetation type (humid evergreen rainforest), we expect that they will have undergone the same climatic and regional vegetation changes in the past. Therefore, our assumption is that any differences between the paleoecological records can be attributed to the effects of basin type and/or basin size, thus enabling a robust assessment of the potential value of palm swamps as repositories of paleoecological data in southern Amazonia; e.g. whether they reflect a history of terra firme, climate-driven vegetation change beyond the swamp, or merely a history of a palm swamp community controlled by local hydrological conditions within the basin. The findings of our study may have implications for the interpretation of other palm swamp records elsewhere in the neotropics, as well as criteria for the selection of appropriate sites for paleoecological analyses and palaeo-data syntheses.

112 If it is found that the Cuatro Vientos record does provide a long-term (multi-millennial) record 113 of vegetation changes beyond the swamp itself, the pairing of Cuatro Vientos and Laguna 114 Chaplin also provides an opportunity to explore the dynamics of local versus regional-scale 115 vegetation changes in the park. This strategy of pairing small and large neighboring 
116 sedimentary basins has long been advocated as a sound approach for differentiating local

117 versus regional pollen catchments in mid to high latitude North America and Europe (Jacobson

118 and Bradshaw, 1981). In these temperate ecosystems, where most tree taxa are wind-

119 pollinated, modelling approaches based upon pollen productivity and dispersal data have led

120 to quantitative estimates of pollen catchment area, whereby large lakes $\left(>5 \mathrm{~km}^{2}\right)$ have

121 regional-scale pollen catchment areas (> 50 ×50-100 × 100 km) and are relatively insensitive

122 to localized or patch-size vegetation changes (Sugita, 1994; Sugita et al., 1999; Davis, 2000;

123 Sugita, 2007a), whereas small lakes $\left(<\sim 0.1-1 \mathrm{~km}^{2}\right)$ instead have local-scale pollen catchment 124 areas $(<\sim 10 \times 10 \mathrm{~km}$ ) (Sugita, 2007b). These temperate ecosystem pollen catchment

125 estimates (e.g. $1 \mathrm{~km}^{2}$ cut-off between local versus regional catchments) are unlikely to hold

126 true for humid tropical rainforests due to the different constituent taxa and far greater

127 complexity of pollination syndromes (wind, insects, bats, birds) associated with these more

128 biodiverse ecosystems. However, in our study area at least, modern pollen rain studies

129 (Gosling et al., 2005, 2009; Burn et al., 2010) show that wind-pollinated Moraceae pollen

130 dominates rainforest pollen assemblages in NKMNP. The general premise that large lakes

131 and small lakes capture regional- and local-scale pollen rain, respectively, therefore likely

132 holds true, corroborated by Carson et al. (2014). The area of the Cuatro Vientos swamp basin

133 is $\sim 5 \mathrm{~km}^{2}$, compared with $\sim 25 \mathrm{~km}^{2}$ for the neighboring Laguna Chaplin basin (Fig. 2), thus

134 enabling local-scale vegetation dynamics (Cuatro Vientos) to be differentiated from regional-

135 scale vegetation dynamics (Laguna Chaplin).

136

137 The local-scale catchment of Cuatro Vientos is particularly pertinent given the location of this 138 site at the margin of the riverine forests of the Río Paraguá (Figs. 1 and 2), as this provides a 139 unique opportunity to investigate the Quaternary history of riverine/gallery rainforest. During 140 drier periods of the Pleistocene when humid evergreen rainforest cover was reduced, it has 141 previously been proposed that rainforest taxa may have survived within refugia provided by 142 riverine gallery rainforest, due to the more continuous water supply from the river (Meave et 143 al., 1991; Meave and Kellman, 1994; Pennington et al., 2000). These gallery rainforest refugia 144 may have provided important routes and source areas for the spread of plant and animal 145 species (Redford and da Fonseca, 1986; Meave et al., 1991; Costa, 2003), as well as 146 providing routes for human population expansion (Iriarte et al., 2017). Investigating the extent 147 of gallery rainforests in NKMNP through the late Quaternary may also help to explain the 148 mechanism of rainforest expansion in the late Holocene, e.g. whether the gallery rainforests 149 served to expedite the spread of rainforest taxa in response to climate change (e.g. Mayle et 150 al., 2007). However, the extent to which these gallery rainforests survived through the drier 151 climatic periods of the LGM and middle Holocene in NKMNP is uncertain, given that, until now, 152 only regional-scale vegetation records are available from pollen data from the two large lakes 
153 in this area (i.e. Lagunas Chaplin and Bella Vista), which lack the spatial resolution to capture 154 changes in the extent of riverine vegetation.

155

This paper addresses the following questions:

1. How does the Quaternary paleoecological record from a small ( $\left.5 \mathrm{~km}^{2}\right)$ Amazonian palm swamp (Cuatro Vientos) in Noel Kempff Mercado National Park (NKMNP) (ecotonal southern Amazonia) compare with that of a neighboring large lake (Laguna Chaplin, $\sim 25 \mathrm{~km}^{2}$ ), and what does this comparison reveal about the suitability of palm swamps as fossil pollen archives for investigating Amazonia's Quaternary vegetation history?

2. What does the palaeoecological record from Cuatro Vientos, located close to a river, reveal about the extent of riverine gallery rainforest in NKMNP during the drier climatic conditions of the LGM and middle Holocene when the interfluves were dominated by savanna and/or semi-deciduous tropical dry forest?

3. What are the implications of this palm swamp study for assessing the role of gallery forest as rainforest migration corridors or refugia under drier climatic conditions? 
171 Noel Kempff Mercado National Park (NKMNP) is a $15,230 \mathrm{~km}^{2}$ protected reserve located near

172 the southern margin of the Amazon basin in north-eastern Bolivia (Fig. 1) (Killeen and

173 Schulenberg, 1998). The park has been designated a UNESCO world heritage site due to its

174 exceptionally high beta (habitat) diversity and is largely undisturbed by modern anthropogenic

175 land use (Killeen et al., 2003; Heyer et al., 2018).

\section{Geomorphology and regional vegetation}

178 NKMNP is located on the western reach of the Precambrian Brazilian shield, the 179 geomorphology of which splits the park into two distinct landscapes (Fig. 1). To the east, the 180 park is dominated by the Huanchaca Plateau, a table-mountain 600-900 $\mathrm{m}$ above sea level 181 (a.s.l) comprized of Precambrian sandstone and quartzite. The plateau is predominantly 182 covered in upland cerrado savanna vegetation that has been present since at least the end of 183 the last glacial period (Maezumi et al., 2015). To the west lies a lowland peneplain, where the 184 Precambrian bedrock is blanketed by Tertiary and Quaternary alluvial sediments and is covered predominantly in terra firme humid evergreen tropical forest (HETF). The clear-water rivers of the Río Iténez and Río Paraguá form the north/eastern and western boundaries of NKMNP, respectively. These rivers and other smaller streams in the park are lined by evergreen riverine forests, usually on the natural levees that form from deposition events during seasonal flooding. Patches of seasonally-inundated savanna occur near the rivers where soil drainage is poor. The southern border of NKMNP defines the modern ecotone between the HETF of southern Amazonia and the Chiquitano semi-deciduous tropical dry forest (SDTF) of eastern lowland Bolivia. The term 'semi-deciduous' is used here to describe the flexible phenologic response (deciduousness) of the constituent trees, depending on the degree and duration of the dry season (Killeen et al., 1998; Killeen and Schulenberg, 1998). In contrast to the HETF, the SDTF supports a denser understorey vegetation as more light can penetrate the canopy.

\section{Climate}

199 The precipitation regime of the region is distinctly seasonal, predominantly controlled by the

200 South American Summer Monsoon (SASM; Zhou and Lau, 1998; Raia and Cavalcanti, 2008;

201 Silva and Kousky, 2012). The majority of the $\sim 1400-1600 \mathrm{~mm}$ mean annual precipitation falls during the wet season during austral summer, with a dry season lasting for 4-6 months during austral winter. Mean annual temperatures are $\sim 25-26^{\circ} \mathrm{C}$, with little monthly variation. 
reach the area and cause temperatures to drop below $10^{\circ} \mathrm{C}$ for several days (Killeen et al., 2003).

\section{Site descriptions}

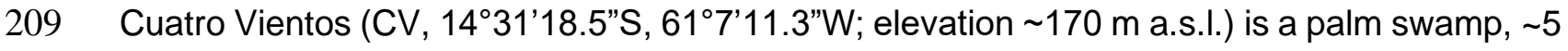

$210 \mathrm{~km}^{2}$ in area, located in western NKMNP, $\sim 5 \mathrm{~km}$ from the Río Paraguá (Figs. 1 and 2). Although

211 it receives river flood waters during the rainy season, it is not an oxbow. As with the large

212 lakes in NKMNP (Lagunas Chaplin and Bella Vista), the oval-shaped CV likely formed either

213 as a solution hollow or subsidence along faults of the underlying siliceous rocks of the Pre-

214 Cambrian Shield. The surrounding vegetation (beyond the palm swamp) consists of terra firme

215 HETF to the east and riverine (riparian) forest of the Río Paraguá immediately to the west.

216 The riverine forests in NKMNP vary in their structure, from young pioneer communities, with

217 trees such as Cecropia, Sapium and Acacia, through to older communities with later

218 successional tree taxa, particularly from the Moraceae family (e.g. Brosimum lactescens,

219 Pseudolmedia spp., Ficus spp.). Most of these species are dioecious and wind-pollinated

220 (anemophilous) and are therefore over-represented in the pollen record due to their prolific

221 pollen production (Bush and Rivera, 2001; Burn et al., 2010). Although similar to communities

222 of terra firme evergreen forests, the riverine forests can be distinguished by their sparse

223 understoreys (due to seasonal flooding), smaller stature, flood-tolerant species and lower

224 overall species diversity (Killeen and Schulenberg, 1998; Burn et al., 2010). Growing within

225 the CV basin itself is a floating mat of sedge/grass swamp vegetation, interspersed with small

226 pools of open water and scattered clumps of Mauritiella palm trees.

228 Laguna Chaplin ( $\mathrm{LCH}, 14^{\circ} 28^{\prime} 12^{\prime \prime} \mathrm{S}, 61^{\circ} 2^{\prime} 60^{\prime \prime} \mathrm{W}$; elevation $\sim 170 \mathrm{~m}$ a.s.l.) is a large $\left(\sim 12 \mathrm{~km}^{2}\right)$, shallow (2-2.5 $\mathrm{m}$ in the dry season), flat-bottomed lake (within a $\sim 25 \mathrm{~km}^{2}$ basin), located $\sim 6.5$ km north-east of CV (Mayle et al., 2000; Burbridge et al., 2004) (Fig. 2). The LCH basin is surrounded by HETF, with a mix of seasonally-inundated riverine forest (around much of the lake margin and along the small, ephemeral streams that flow in and out of LCH) and terra firme (upland) HETF. Adjacent to the lake, in the southern half of the basin, lies a patch of savanna wetland. Comparison of the modern pollen spectra of the surface sediments of the lake (Burbridge et al., 2004) with pollen trap data from all the constituent plant communities in NKMNP (Gosling et al., 2005; Burn et al., 2010; Jones et al., 2011) reveals that the modern pollen assemblage of this lake originates from both the riverine and terra firme HETF ecosystems in the lake catchment. Crucially, however, the regional-scale pollen source area of this large lake means that differentiation of the relative extent of riverine versus terra firme ecosystems is not possible. Both $\mathrm{LCH}$ and $\mathrm{CV}$ are located $\sim 30 \mathrm{~km}$ from the modern HETF/SDTF ecotone at the southern limit of NKMNP (Fig. 1). 


\section{Sediment core}

245 Cuatro Vientos (CV) was cored in August 1995 by FM with a modified square-rod Livingstone

246 piston corer (Wright, 1967). The core location was $\sim 300 \mathrm{~m}$ from the eastern edge of the palm

247 swamp (Fig. 2), with the inherent difficulty in traversing swamp environments making it

248 impossible to penetrate further into the basin. The top $20 \mathrm{~cm}$ of the core site comprized a

249 floating mat of grasses and sedges. Below this was a $\sim 1 \mathrm{~m}$ water column, the bottom of which

250 was well mixed with the soft uppermost sediment making it difficult to determine the depth of

251 the sediment-water interface. Therefore, core depths were recorded by reference to the top of

252 the floating mat vegetation (FMV). A $154 \mathrm{~cm}$ core was recovered, between 155 and $309 \mathrm{~cm}$

253 below the surface of the FMV. Unfortunately, the sediment above $155 \mathrm{~cm}$ was too soft to be

254 recovered. Lithological descriptions are based on the color (using a Munsell soil color chart)

255 and texture of the sediment core. Loss-on-ignition (LOI) analysis was carried out at $4 \mathrm{~cm}$

256 intervals through the CV core. After drying at $100^{\circ} \mathrm{C}$ for 24 hours, each $1 \mathrm{~cm}^{3}$ sample was

257 combusted at $550^{\circ} \mathrm{C}$ for 2 hours $\left(\mathrm{LOI}_{550}\right)$. The relative loss of weight before and after

258 combustion determines the percentage organic carbon content that was present in that

259 sample (Dean, 1974; Heiri et al., 2001).

260

\section{Chronology}

262 The chronological framework for CV is based on 9 Accelerator Mass Spectrometry (AMS)

263 radiocarbon $\left({ }^{14} \mathrm{C}\right.$ ) dates (Table 1 ). Due to the absence of sufficient plant macrofossils, the

264 majority of the dates were obtained from non-calcareous bulk sediment. However, two of the

265 samples (Beta-467884 and Beta-467885) contained enough decayed plant remains during

266 pre-treatment to be dated. All samples selected for dating were treated to remove any

267 carbonates, and the plant remains were treated to remove mobile humic acids. Radiocarbon

268 ages were calibrated using the IntCal13 calibration curve (Reimer et al., 2013), and a 269 chronology was constructed using the Bayesian age modelling software Bacon v2.3.4 (Blaauw

270 and Christen, 2011). The IntCal13 calibration curve was chosen over SHCal13 because of the

271 hydrological connection of the study area to the northern hemisphere, via the SASM

272 (McCormac et al., 2004; Hogg et al., 2013).

273

274 Pollen analysis

275 The CV core was sub-sampled for pollen analysis at $4 \mathrm{~cm}$ intervals, apart from between 220$276252 \mathrm{~cm}$ where sub-samples were taken at $2 \mathrm{~cm}$ intervals. The last $29 \mathrm{~cm}$ of the core (280$277309 \mathrm{~cm}$ ) was unsuitable for pollen analysis as the sediment had oxidized, preventing pollen 278 preservation. For each horizon, $1 \mathrm{~cm}^{3}$ of sediment was prepared for pollen analysis using 279 standard protocols (Faegri and Iversen, 1989), including hot treatments of $40 \% \mathrm{HF}$ and $10 \%$ 
$280 \mathrm{NaOH}$. Samples particularly rich in clay were given pre-treatments of hot $5 \%$ sodium

281 pyrophosphate to help disperse the clays, but were not subjected to a fine-sieving stage to 282 ensure small grains $(<5 \mu \mathrm{m})$ were retained. A known concentration of the exotic marker spore 283 Lycopodium clavatum was added to each sample so that absolute pollen concentrations could 284 be calculated (Stockmarr, 1971). Prepared samples were mounted in silicone oil and were 285 counted to the standard 300 Terrestrial Land Pollen (TLP) sum. Cyperaceae pollen was 286 included in the TLP sum (as per Laguna Chaplin, Burbridge et al., 2004) as this taxon is important in the seasonally-flooded savannas of the study region. Pollen identifications were made with reference to published tropical pollen atlases (Roubik and Moreno Patiño, 1991; Colinvaux et al., 1999; Lorente et al., 2017), a freeware digital database of neotropical pollen (Bush and Weng, 2007), and an extensive modern neotropical pollen reference collection of $>1500$ specimens housed at the laboratory of the Tropical Palaeoecological Research Group, University of Reading. Pollen of the Moraceae/Urticaceae families were grouped into a single 'Moraceae' category (with the exception of Cecropia). It is notoriously difficult to distinguish between these families and their genera, and given the grains from CV were often obscured or damaged, there was little confidence in genus-level identification, even with the help of published morphological descriptions (Burn and Mayle, 2008). Zones for the pollen data were drawn based on a stratigraphically constrained cluster analysis by incremental sum of squares (CONISS; Grimm, 1987), with the number of statistically significant zones evaluated using the broken-stick model (Bennett, 1996). All analyses and plotting of the pollen data were performed in R (v.3.4.4), using the rioja (v.0.9-15.1) and vegan (v.2.4-6) packages (Juggins, 2017; Oksanen et al., 2018).

302

\section{Laguna Chaplin core}

304 Laguna Chaplin (LCH) was cored in 1998 by FM, with the methodology and results of the paleoecological analyses presented in subsequent publications (Mayle et al., 2000; Burbridge et al., 2004; Maezumi et al., 2018b). The pollen data from the analyses of LCH are presented here and compared with those of CV to provide the necessary regional-scale, late Quaternary vegetation and climate context for determination of the paleoecological significance of the CV palm swamp fossil pollen record. We replot the LCH data with an updated age-depth model because the original age-depth model was based on simple linear interpolation between consecutive radiocarbon dates (Burbridge et al., 2004) - a method no longer favored in the paleoenvironmental community (Blaauw et al., 2018). The chronological framework for LCH presented here is based on 14 Accelerator Mass Spectrometry (AMS) radiocarbon $\left({ }^{14} \mathrm{C}\right)$ dates

314 (Table 2) and, as with CV, uses the Bacon Bayesian age modelling software package (Blaauw 315 and Christen, 2011). Note that only the 0-24,000-year portion of the 40,000-year LCH pollen record is plotted here, to allow direct comparison with the 24,000-year CV pollen record. 


\section{RESULTS}

\section{Cuatro Vientos - core stratigraphy and chronology}

319 Figure 3 shows the age-depth model derived from Bacon. The model used 7 of the $9{ }^{14} \mathrm{C}$ AMS

320 dates, with the dates at $240 \mathrm{~cm}$ and $276 \mathrm{~cm}$ rejected based on Bacon's outlier identification.

321 The date at $240 \mathrm{~cm}$ was based on a particularly small sample size of extracted decayed plant

322 remains, raising the possibility that the younger-than-expected age could be due to down-core

323 movement of the sample. The date at $276 \mathrm{~cm}$ is consistently rejected by multiple Bacon runs,

324 as well as through an exploratory run of OxCal's statistical outlier model (Bronk Ramsey, 1995,

325 2009), and may be anomalously old due to incorporation of older, reworked sediment. The

326 dates for the top $(155 \mathrm{~cm})$ and bottom $(309 \mathrm{~cm})$ of the core are based on extrapolation, and

327 so must be interpreted with care.

329 The sediments from CV can be split into three main stratigraphic sections (Fig. 3).

330 (1) 309-255 cm: comprized of inorganic greyish-brown silty clay, with a sedimentation rate of

331 ca. $0.05 \mathrm{~mm} / \mathrm{yr}$. The age range of this section is ca. $33,000-28,000$ to $19,000-16,000$ cal

332 years BP, corresponding to the late Pleistocene and including the last glacial maximum (LGM).

333 The upper boundary of $255 \mathrm{~cm}$ likely marks a hiatus in the core lasting from ca. 19,000-16,000

334 to $12,000-10,500$ cal years BP.

335 (2) 255-230 cm: comprized of gray, silty clays, with some organic inclusions. This section 336 corresponds to the early Holocene, between ca. 12,000-10,500 and 8000-7500 cal years BP.

337 A particularly sandy layer of sediment is present within this section, between ca. $238-232 \mathrm{~cm}$

338 where pollen preservation is very poor. Sedimentation rates increase to ca. $0.07-0.1 \mathrm{~mm} / \mathrm{yr}$.

339 (3) 230-155 cm: comprized of poorly humified black detrital peat with an increased 340 sedimentation rate of ca. $0.2-0.3 \mathrm{~mm} / \mathrm{yr}$. The age range of this section is ca. $8000-7500$ to 4000-3000 cal years BP, spanning the middle Holocene and part of the late Holocene.

\section{Cuatro Vientos pollen data}

344 Figure 4 shows the fossil pollen data for the CV core between 155 and $280 \mathrm{~cm}$ (below FMV 345 surface). Three statistically significant zones were identified in the cluster analysis, but to aid 346 in interpretation, zone 1 was split into two sub-zones (before and after the hiatus) and an 347 additional zone was added to mark the period of poor pollen preservation between 239 and $348230 \mathrm{~cm}$ (zone 2), thus giving a total of four pollen assemblage zones. The results of CV will 349 be discussed alongside the updated pollen diagram from LCH (Figs. -6).

351 Zone 1a and Zone 1b: 280-240 cm, ca. 24,000-8750 cal yr BP (LGM to Early Holocene); 352 includes sediment hiatus ca. 18,000-11,000 cal yr BP 
This pollen assemblage has abundant grass (Poaceae; 40-60\%) and sedge (Cyperaceae; 5$10 \%$ ) pollen, and the highest abundance of the herb taxa Asteraceae (5-10\%), Borreria ( 2\%) and Amaranthaceae $(\sim 1 \%)$. Levels of 'cold-adapted' taxa such as Podocarpus, Alnus, and Ilex peak in this zone, though at low levels of up to $1 \%$. This is the only zone to contain any significant amounts of Paullinia/Roupala; levels of this pollen type are consistent at 3-5\% for most of the zone, rising to $\sim 10 \%$ near the top of the zone. The savanna indicator Curatella americana is present, but in low amounts $(<1 \%)$. Other arboreal taxa are limited, with low quantities $(<3 \%)$ of Moraceae, Celtis, Arecaceae (palms), and Alchornea - although Alchornea reaches it's highest abundance in this zone. Few grains were recovered of the aquatic/semi-aquatic taxa Sagittaria and Isoetes. In general, the pollen grains recovered in these zones were often degraded. $\mathrm{LO}_{550}$ values are consistently low ( 5-10\%) throughout these zones, reflective of the inorganic, silty clay sediment.

Zone 2: 239-230cm, ca. 8750-7000 cal yr BP (early-middle Holocene)

Pollen preservation in this zone was very poor, most likely a result of the coarse sandy sediment damaging the grains.

Zone 3: $230-206 \mathrm{~cm}$, ca. $7000-5500$ cal yr BP (middle Holocene)

371 During this mid-Holocene section of the core, pollen characteristic of SDTF become established, including Anadenanthera (2-4\%), Astronium (5-7\%) and the understorey taxon Clavija (3-5\%). At the same time, Curatella americana becomes more abundant (2-4\%) and Poaceae levels remain consistent at $50-60 \%$. Other arboreal taxa remain at low levels, although Moraceae does increase slightly from $4 \%$ to $10 \%$. Palm taxa are uncommon in this zone. Levels of weed and herb taxa (e.g. Asteraceae, Borreria) as well as the 'cold-adapted' taxa found in Zone 1, decrease to negligible amounts. The aquatic/semi-aquatic taxa Sagittaria and Isoetes increase throughout this zone, with Sagittaria in particular becoming a large proportion of the total pollen sum ( 20\%) between ca. $6000-5500 \mathrm{cal}$ yr BP. A sudden increase in $\mathrm{LO}_{550}$ occurs at ca. 6,000 cal yr BP (from $<20$ to $~ 80 \%$ ), reflecting the switch from clay to organic, peaty sediment (Fig. 3).

382

Zone 4: 206-155cm, ca. 5500-3750 cal yr BP (middle to late Holocene)

384 This zone is similar to zone 3 , with only subtle differences in the abundances in some of the taxa. Moraceae percentages stabilize at $\sim 10 \%$, with other HETF arboreal taxa remaining at low/negligible levels. Palm (Arecaceae spp., Mauritia/Mauritiella) pollen grains have a more consistent presence in the assemblage, being present in most samples within this zone, but only at very low levels $(<1 \%)$. Curatella americana decreases slightly towards the top of this zone. Sagittaria becomes established at $20-30 \%$ of the total pollen sum, with Isoetes 
390 decreasing slightly from Zone 3 a to values of $0-5 \%$. LOI ${ }_{550}$ values remain consistent at $~ 90 \%$

391 through this zone.

\section{INTERPRETATION and DISCUSSION}

393 Comparison between pollen records of Cuatro Vientos palm swamp and Laguna 394 Chaplin

395 Last glacial maximum (ca. 24,000-18,000 cal yr BP)

396 The paleoecological data indicate that the Cuatro Vientos (CV) basin was markedly different 397 during the LGM compared with today. The scarcity of palms (Arecaceae undiff. and 398 Mauritia/Mauritiella) in the pollen record is a clear indication that, unlike today, there were no 399 substantial stands of palm trees growing on or near the basin during this time. Additionally, 400 Mauritiella palm swamps, such as CV, are characterized by highly organic, peaty sediment. 401 However, this LGM section of the core is characterized by fine-grained inorganic clay sediment $402\left(<10 \% \mathrm{LOI}_{550}\right)$, suggestive of a low-productivity, low-energy lake rather than a peat swamp. 403 The absence of emergent macrophytes (e.g. Sagittaria, Isoetes) suggests that CV was 404 unsuitable for supporting aquatic/semi-aquatic vegetation, possibly indicating very low water levels and the basin perhaps drying out seasonally. Low water levels would be consistent with the regional paleoclimate reconstructions of a drier LGM in this region, not only from neighboring LCH (Burbridge et al., 2004), but also Laguna La Gaiba 500 km to the south (Whitney et al., 2011; Metcalfe et al., 2014). An intermittently dry basin may also account for the generally degraded nature of the pollen grains in this section of the core, whereby the grains are exposed to short-term oxidation. We acknowledge the possibility that differential pollen preservation of different taxa may conceivably introduce a degree of bias into these pollen assemblages, although no significant taxonomic bias was apparent when counting the pollen.

If our interpretation that CV was an open lake (rather than a palm swamp) at this time is correct, the LGM pollen assemblage would reflect the local vegetation growing outside the basin, rather than within the basin. This gives us confidence that CV is a useful repository of paleoecological data during the LGM, reflecting the history of terra firme vegetation changes beyond the basin. Therefore, any significant differences between the pollen records of LCH and CV will most likely be a result of basin size (i.e. regional versus local pollen catchments, respectively), rather than basin type (i.e. lake versus palm swamp). Although CV today receives flood water from the neighboring clear-water Rio Paragua during the rainy season, and likely did so throughout its late Quaternary history, we are confident that this riverine pollen input is negligible compared with terrestrial pollen sources to the lake, based on modern pollen-vegetation comparisons from several other flood-water lakes across lowland Bolivia. 
vegetation in the case of small lakes such as L. Granja (Carson et al., 2014) or regional terrestrial vegetation with respect to large lakes such as L. Chaplin (Mayle et al., 2000), L. La

429 Gaiba (Whitney et al., 2011), and L. Oricore (Carson et al., 2014 ), despite receiving seasonal

430 flood waters from neighboring rivers.

The LGM pollen records from CV and LCH are remarkably similar (Figs. -6), both indicating an open landscape covered with grasses, herbs and sparse tree cover typical of an open savanna. There is abundant Poaceae alongside relatively high percentages of other terrestrial herbs (Borreria, Asteraceae) and Cyperaceae. The modern pollen rain study of Jones et al. (2011), based on pollen trap samples from 1 ha ecological plots within NKMNP, suggests that this type of assemblage may be characteristic of an open seasonally-flooded savanna, favoring herbaceous plants that cope better with contrasting seasonal water stresses. Although they are negligible in the CV record, Mauritia/Mauritiella palms are slightly more abundant in LCH, which Burbridge et al. (2004) and Jones et al. (2011) use as further evidence of a seasonally-flooded savanna. Nevertheless, Jones et al. (2011) note that the differences between seasonally-flooded and terra-firme cerrado savanna are subtle, and the LGM landscape was most likely a mix of these two savanna types. The presence of the woody savanna tree Curatella americana is noteworthy as this is a key indicator of savanna environments. Within a seasonally-flooded environment, this species typically grows on top of termite mounds to avoid waterlogging (Killeen and Schulenberg, 1998; Jones et al., 2011); this limited growing area may explain the small quantities of Curatella americana in this section of the core, though the fact this species is hermaphroditic and entomophilous (insectpollinated) will also be a key factor in it being under-represented in the pollen record. Overall, the similarities in the pollen records of $\mathrm{CV}$ and $\mathrm{LCH}$ show that the local-scale vegetation (CV) was similar to the regional-scale vegetation $(\mathrm{LCH})$, corroborating the interpretations from Burbridge et al. (2004) that much of southern NKMNP was covered in an open savanna during the LGM in response to glacial aridity, lower atmospheric $\mathrm{CO}_{2}$ levels (Monnin et al., 2001) and cooler temperatures (Stute et al., 1995; Thompson et al., 1998; Whitney et al., 2011).

456 Burbridge et al. (2004) infer that the low levels of arboreal rainforest taxa at LCH most likely indicate scarce communities of HETF regionally, most likely existing as gallery rainforests bordering the Río Paraguá. However, the extent of these gallery rainforests is impossible to determine with the regional-scale pollen catchment of $\mathrm{LCH}$. Given that we have established that the LGM pollen record from CV is representative of vegetation growing beyond its basin, the smaller catchment size of CV and the basin's closer proximity to the Río Paraguá allows us to gain more information about the gallery rainforests at this time. Modern pollen rain 
464

Moraceae levels of at least $40 \%$, alongside pioneer species such as Cecropia and potentially small abundances of taxa such as Pouteria, Sapium and Symmeria (Gosling et al., 2005; Burn et al., 2010). However, the LGM pollen assemblages of CV are not indicative of this kind of gallery rainforest. In particular, Moraceae and Cecropia percentages never exceed $\sim 5 \%$, which, given that these taxa are prolific pollen producers and are over-represented in pollen assemblages (Gosling et al., 2005; Burn et al., 2010), is strong evidence against a substantial gallery rainforest lining the nearby Río Paraguá.

Following Zone 1a, the sediment hiatus at CV from ca. 18,000-11,000 cal yr BP suggests a period of very dry conditions, perhaps causing the basin to dry out completely. Similar hiatuses or periods of low sedimentation have been identified in other basins across lowland Amazonia during the last glacial period, for example: in NKMNP, Laguna Bella Vista (LBV; ca. $110 \mathrm{~km}$ north of CV) records a hiatus between ca. 42,500-13,000 cal yr BP and LCH records very low sedimentation rates during this period (Burbridge et al., 2004); in south-eastern Amazonia, hiatuses are recorded on the Serra dos Carajás plateau between ca. 22,000-13,000 cal yr BP (Sifeddine et al., 2001) and at Lago do Saci between ca. 18,200-9200 cal yr BP (Fontes et al., 2017); several basins outlined in Ledru et al. (1998) from across Amazonia and southern Brazil record low sedimentation or hiatuses spanning the LGM.

\section{Early to middle Holocene (ca. 11,000-7000 cal yr BP)}

The end of the sediment hiatus at CV occurred at ca. 11,000 cal yr BP and is concurrent with the slight change in the lithology of the sediment, with grayer clays and some organic inclusions. Nevertheless, there is no evidence that the basin changed significantly from the shallow open lake of the LGM; the LOI ${ }_{550}$ values remain low and there is no change in the levels of sedge, aquatic or palm taxa. The hiatus termination may indicate slightly wetter conditions in the region, allowing water levels in the basin to rise and for local runoff to increase, inputting more sediment to the basin. The latter is consistent with the paleoclimatic interpretation of increased precipitation levels from ca. 12,200 cal yr BP at Laguna La Gaiba (Whitney et al., 2011) and with the hiatus termination at LBV in the north of NKMNP (Burbridge et al., 2004). Holocene temperatures were ca. $5^{\circ} \mathrm{C}$ higher than the LGM, with deglacial warming of tropical South America occurring from ca. 19,500 cal yr BP (Seltzer et al., 2002; Whitney et al., 2011). Atmospheric $\mathrm{CO}_{2}$ levels in the Holocene were ca. 76 ppm higher than the LGM (Monnin et al., 2001). Both temperature and $\mathrm{CO}_{2}$ levels remained relatively stable throughout the Holocene, prior to the industrial period (Indermühle et al., 1999; van Breukelen et al., 2008; Whitney et al., 2011). 

from that of the LGM Zone 1a, which suggests that the open savanna persisted in the area into the early Holocene. This pollen assemblage is consistent with that of $\mathrm{LCH}$, which is relatively stable from the LGM through most of the Holocene (including through the hiatus phase at $\mathrm{CV}$ ). Therefore, even with the increase in precipitation at this time (restarting sedimentation at CV), it clearly wasn't enough to support a humid arboreal landscape. The period of poor pollen preservation in the CV core from ca. 8750 to $7000 \mathrm{cal}$ yr BP (Zone 2) is associated with a layer of sandy sediment. This may reflect a period where fluvial dynamics caused a change in river course so that it flowed near, or even into, CV, therefore creating a higher-energy deposition environment. A higher-energy environment would inhibit deposition of pollen-size particles, instead favoring the deposition of the larger, heavier sand particles, thus potentially explaining the lack of pollen in this section of the core. Additionally, agitation

512 of the pollen grains against the large sandy grains could have caused mechanical damage 513 and poor pollen preservation (Twiddle and Bunting, 2010). In the absence of bracketing C-14 514 dates, the rate of accumulation of this sandy layer is uncertain, although it is conceivable that it was deposited very rapidly, perhaps as a single flood pulse from the neighboring river.

Middle Holocene (ca. 7000-5500 cal yr BP)

518 It has been well established that the middle Holocene was associated with a significantly drier519 than-present climate across much of southern hemispheric tropical South America, with peak 520 dryness occurring at ca. 6000 cal yr BP (Baker et al., 2001; Wang et al., 2007; Whitney and 521 Mayle, 2012; Cheng et al., 2013; Kanner et al., 2013; Bernal et al., 2016). The drier climate has been attributed to lower southern-hemispheric summer insolation levels at this time, driven by the precessional cycle of Earth's orbit (Berger and Loutre, 1991), which would have acted to restrict the southerly migration of the Inter-tropical Convergence Zone (Haug et al., 2001) and decrease the strength of the South American summer monsoon (Cruz et al., 2009; Baker and Fritz, 2015).

The mid-Holocene section of the CV core is marked by significant changes to the CV basin, in particular, a switch to highly organic ( LOI $_{550}$ values > 80\%), peaty sediment ca. 6000 cal yr BP (Fig. 3). Concurrent with this dramatic lithological change is increased abundance of the aquatic/semi-aquatic macrophytes Sagittaria and Isoetes. These changes suggest a change from a clear, shallow, open lake to a more eutrophic environment with high levels of deposition of organics. We infer that this is the start of the transition of CV from a lake to a palm swamp.

534 The timing of this switch is interesting, given that it occurs at the peak of the mid-Holocene 535 drought at ca. $6000 \mathrm{cal}$ yr BP and previous dry conditions during the LGM were associated with low sedimentation rates and a sediment hiatus at CV. A drier mid-Holocene climate would 
537 most likely cause a decrease in water levels at CV, but unlike at the LGM, the closer river 538 channel (as argued for in the early-Holocene Zone 2) would cause intermittent flooding at CV 539 inundating the basin with organic matter and maintaining an anaerobic environment.

540 Nevertheless, it is important to note that there is a great diversity of successional pathways in 541 swamp environments that can be caused by a variety of different factors (Behling and 542 Hooghiemstra, 1999; Kelley et al., 2013; Roucoux et al., 2013) which may or may not be 543 related to changes in precipitation. It is possible that this change from inorganic lacustrine 544 sediments to a peat swamp environment reflects hydrarch succession of the basin, whereby 545 a critical ecological threshold or 'tipping point' has been exceeded.

547 Despite the change of CV to a swamp basin at this time, we can remain reasonably confident 548 that vegetation growing in the swamp is not masking the influx of pollen from vegetation 549 beyond the swamp. Other than the increase in emergent aquatics (Sagittaria, Isoetes), there 550 are no increases in other taxa that would be expected to grow in a swamp environment and dominate the pollen rain (e.g. Cyperaceae, Mauritia/Mauritiella). Increases in pollen percentages of arboreal taxa that do not grow in a swamp environment (e.g. Astronium,

553 Anadenanthera) are especially significant, as pollen of these taxa must have come from the surrounding terra firme area beyond the perimeter of the basin. Therefore, as with the LGM, this gives us confidence that $\mathrm{CV}$ is a useful repository of mid-Holocene paleoecological data, reflecting the history of terra firme vegetation changes beyond the basin.

558 Considering the clear contrast in the type (palm swamp versus lake) and size (5 versus 20 $\mathrm{km}^{2}$ ) of the CV basin compared with the neighboring LCH basin, it is perhaps surprising that the pollen records of these two sites are so similar. Both records are indicative of a savannaSDTF mosaic landscape during this mid-Holocene pollen assemblage. The increased levels of the savanna tree Curatella americana, decreased levels of herbs (e.g. Asteraceae) and negligible amount of palm taxa at both sites may suggest that the savanna component was more indicative of a woody cerrado (non-flooded) savanna, rather than the more open seasonally-inundated savanna of the LGM (Jones et al., 2011). This interpretation is plausible given that a weaker mid-Holocene summer monsoon would likely mean less flooding (from the neighboring Río Paraguá) in the rainy season and longer dry seasons. The establishment of Anadenanthera and Astronium is good evidence of SDTF being present around the basins at this time, both locally $(\mathrm{CV})$ and regionally $(\mathrm{LCH})$, as these are key components of modern SDTF. The Anadenanthera pollen type is most likely Anadenanthera colubrina, a key droughttolerant species that is dominant in the modern Chiquitano SDTF region (Killeen and

572 Schulenberg, 1998; Gosling et al., 2009) and a key dry forest indicator, given its absence from 573 both rainforest and savanna ecosystems (Gosling et al., 2009). Both Anadenanthera and 
574 Astronium are often under-represented in pollen assemblages $(<1 \%$ in modern pollen traps;

575 Gosling et al., 2009); therefore, the relatively high percentages of these taxa (5-7\%) suggests

576 they would have been abundant in the area. The similarity between the CV and LCH pollen

577 records provides good evidence that the drier climate of the middle Holocene caused a

578 widespread savanna-SDTF mosaic landscape in the area, at both local (evidenced from CV)

579 and regional (evidenced from LCH) spatial scales.

581 The shifting river course into and out of CV that we infer from Zones 2 and 3 suggests that the

582 Río Paraguá ran just as close, if not closer, to CV during the middle Holocene compared with

583 present. Therefore, we may expect that $\mathrm{CV}$ would capture a strong gallery rainforest signal in

584 the pollen record. However, as with the previous pollen zones, there are only low levels of

585 arboreal rainforest pollen taxa at CV (10\% Moraceae), certainly not at the levels (> 40\%

586 Moraceae) expected from a significant gallery rainforest (Burn et al., 2010). We therefore infer

587 that there was insufficient gallery rainforest in NKMNP to provide significant refugia for

588 rainforest species during the drier climate of the middle Holocene. This is somewhat 589 corroborated by other records in southern Amazonia; for example, Laguna Granja, a small

590 oxbow lake ca. $300 \mathrm{~km}$ northwest of NKMNP, also shows reduced extent of gallery rainforests

591 during the middle Holocene (Carson et al., 2014).

592

593 Middle to late Holocene (ca. 5500-3750 cal yr BP)

594 Following the peak of the mid-Holocene dry period at ca. $6000 \mathrm{cal}$ yr BP, the climate in the 595 region gradually became wetter through the middle to late Holocene (especially after ca. 4,000 596 cal yr BP) (Baker et al., 2001; Wang et al., 2007; Whitney and Mayle, 2012; Cheng et al., 597 2013; Kanner et al., 2013; Bernal et al., 2016) in response to progressive strengthening of the 598 SASM driven by gradually increasing insolation levels (Berger and Loutre, 1991; Cruz et al., 599 2005; Baker and Fritz, 2015). In CV Zone 4, the organic, peaty sediment with consistently high 600 LOI $_{550}$ values is now well established, indicating that the basin has remained a swamp 601 throughout this zone. Aquatic vegetation is well represented, with consistently high levels of 602 Sagittaria, possibly outcompeting Isoetes for space and indicating a continued eutrophic 603 status. However, given that the levels of Cyperaceae and palm taxa remain mostly 604 unchanged, it is unlikely that the basin has yet become a palm swamp analogous to that of 605 today (with the floating mats of grass/sedges and clumps of palms growing throughout the 606 basin). The small increase in percentages of Mauritia/Mauritiella pollen is noted, although if 607 these palms were growing abundantly across the CV basin we would expect much higher 608 levels than the 1-3\% seen here. Our interpretations are hampered by the absence of surface609 sediment samples from CV, which prevents us from determining the pollen signature of the 610 present-day palm swamp. Nevertheless, Mauritia/Mauritiella pollen percentages of between 
611 10-40\% are common for other palm swamps across Amazonia (Behling et al., 1999; Meneses

612 et al., 2015; Rodriguez-Zorro, 2017; Maezumi et al., 2018a) and are therefore likely

613 representative of the modern CV palm swamp as well.

614

615 At both $\mathrm{CV}$ and $\mathrm{LCH}$, only small changes occur in the pollen assemblages between Zone 3 616 and 4, with no changes to the overall interpretation of a savanna-SDTF mosaic vegetation 617 cover both locally (around CV) and regionally (inferred from LCH). There are some subtle 618 differences, however, that may indicate some minor changes to the vegetation cover. The 619 small increase in Moraceae in Zone 4 may signify a greater proportion of SDTF relative to 620 savanna in the region, given that: (a) an increase to $40 \%$ Moraceae would be expected from 621 significant expansion of HETF or gallery rainforest (Burn et al., 2010), and (b) the presence of 622 Moraceae in the modern pollen rain of savanna ecosystems is predominantly due to long623 distance wind-blown transport from the nearby HETF that was absent in the middle Holocene 624 (Gosling et al., 2009; Jones et al., 2011). The slight increase in Mauritia/Mauritiella at CV is 625 concurrent with larger increases seen at $\mathrm{LCH}$, which may suggest the resumption of seasonal 626 flooding at some low-lying areas around the basins. Unfortunately, the CV record terminates 627 at ca. 3750 cal yr BP due to the difficulty in acquisition of uppermost sediments beneath a 628 floating mat of sedge/grass. This means that we cannot corroborate the timing of the increase 629 in HETF at LCH from ca. 2500 to 750 cal yr BP (Burbridge et al., 2004) or determine when the 630 current hydrology developed or when the expansion of palms across the swamp occurred.

\section{Implications of the paleoecological history of Cuatro Vientos}

633 Although great strides have been taken in recent years, the number of paleoecological sites 634 that provide information about the Quaternary vegetation history of tropical South America is well below that of the temperate regions of North America and Europe. A recent mid- to late

636 Holocene multi-proxy vegetation reconstruction synthesis by Smith and Mayle (2018) reports 637110 sites across southern hemispheric tropical South America, although many of these sites 638 were non-pollen based and were clustered in south-east Brazil, with significant gaps across 639 eastern and central Amazonia. Far fewer sites extend to glacial times, with Marchant et al. 640 (2009) reporting only 34 sites for the whole of Latin America in a pollen-based biome 641 reconstruction of the LGM. In contrast, there is good spatial coverage of several hundred mid642 Holocene sites across North America (e.g. Prentice et al., 1993; Sawada et al., 2004; Viau et 643 al., 2006) and Europe (e.g. Davis et al., 2003; Wu et al., 2007; Roberts et al., 2018), with 644 growing numbers in east Asia (e.g. Ni et al., 2010; Tian et al., 2017). As a result, tropical South 645 America remains poorly represented in global syntheses (e.g. Gajewski, 2008; Bartlein et al., 646 2011) and paleodata-model inter-comparison projects (e.g. Kohfeld and Harrison, 2000; 647 Harrison and Prentice, 2003; Braconnot et al., 2012), despite the important role the Amazon 
648 rainforest plays in global biogeochemical cycling (Phillips et al., 2009; Pan et al., 2011; Aragão 649 et al., 2014, 2018).

651 However, increasing the number of sites in tropical regions such as Amazonia is a complicated

652 task and selecting new target sites for paleoecological analysis is limited by site availability.

653 The challenging logistics of field work in Amazonia means that field seasons are often months 654 long and may only yield data from one or two sites. Therefore, researchers may be reluctant 655 to spend limited time and resources to investigate palm swamps for paleoecological study, 656 given the aforementioned concerns over their suitability for recording terrestrial vegetation 657 history from beyond their basin. Consequently, palm swamps are often viewed as 'sub658 optimal' compared with lakes as targets for paleoecological study. However, key lessons to 659 be drawn from the CV record are that: a) Amazonian swamp pollen records can provide useful 660 millennial-scale archives of climate-driven, terrestrial vegetation change beyond the swamp 661 margin, and b) one cannot assume that a palm swamp has always been a palm swamp - a 662 static wetland plant community reflecting purely local-scale basin hydrology, unchanging 663 through time, and unrelated to climate-driven vegetation dynamics elsewhere. Our CV study 664 reveal the importance of considering the potentially dynamic limnological histories of such 665 basins and shows that their present-day characteristics may not be representative of the entire 666 Quaternary sedimentological or catchment history; i.e. Pleistocene lakes with clay sediments 667 have evolved into palm swamps accumulating peat. Within the context of the regional-scale 668 Quaternary vegetation history from neighboring $\mathrm{LCH}$, we have shown that the CV palm swamp 669 was once a lake and contains a fossil pollen archive of local-scale, terrestrial, climate-driven 670 vegetation dynamics extending to the LGM, rather than a localized Quaternary history of a 671 palm swamp plant community. Given the scarcity of Amazonian sedimentary records that 672 extend to the LGM, palm swamps may therefore hold considerably greater value for 673 reconstructing Amazonian Quaternary vegetation change than commonly assumed.

675 With regards to the history of riverine/gallery rainforests in NKMNP, the CV pollen record 676 shows that gallery (riverine) rainforest was either absent, or highly limited in extent, along the 677 neighboring Paragua river during the LGM and middle Holocene. Instead, our pollen data 678 reveal that during the LGM and middle Holocene, both the interfluves and riverine areas 679 (presently covered by humid rainforest) were instead covered by a mosaic of savanna and dry 680 forest. Therefore, our findings do not support the hypothesis, at least in our ecotonal area of 681 Amazonia, that during the LGM and middle Holocene wide ribbons of gallery rainforest lined 682 the rivers, providing important refugia for rainforest species. Narrower or non-existent gallery 683 forests during the middle Holocene may have implications for the migration routes of pre684 Colombian humans. For example, forest dwelling cultures such as the Tupi-Guarani likely 
685

686

687

688

689

690

691

692

693

694

695

696

697

698

699

700

701

702

703

704

705

706

707

708

709

710

711

712

713

714

715

716

717

718

719

720

721

used gallery forests as routes for expansion through non-forested landscapes (Iriarte et al., 2017). If the reduced extent of riverine gallery forests in NKMNP is representative of rivers across ecotonal southern Amazonia, as well as the Cerrado savanna biome to the southeast, it would support the hypothesis that the late Holocene expansion of gallery rainforest (e.g. Silva et al., 2008) linking the Amazonian and Atlantic forest biomes facilitated the transcontinental migration of the forest-dependent Tupi-Guarani culture from southern Amazonia to southern Brazil ca. 2000-3000 cal yr BP (Iriarte et al., 2017).

The vulnerability of the gallery rainforests in NKMNP to drier mid-Holocene climatic conditions, revealed from the CV record, raises concern over the fate of ecotonal areas of Amazonia under drier climate scenarios predicted for the mid-to-late $21^{\text {st }}$ century (Christensen et al., 2017; Joetzjer et al., 2013; Boisier et al., 2015). Modern field-based ecological impact analyses have shown that tree mortality increases significantly in Amazonian forests in response to severe drought events, although regrowth occurs in subsequent wet years (Phillips et al., 2009; Doughty et al., 2015; Feldpausch et al., 2016). However, these drought events are likely to become more frequent under a future drier climate and if gallery rainforests are not likely to provide refugia for rainforest species, then the resilience of ecotonal, southern Amazonian rainforest would likely be reduced.

\section{CONCLUSIONS}

The fossil pollen data from the Cuatro Vientos (CV) palm swamp provide a local-scale, late Quaternary vegetation history for southern Noel Kempff Mercado National Park (NKMNP), Amazonian Bolivia, spanning the last glacial maximum (LGM) to the middle Holocene. This local-scale vegetation history complements the previously published, regional-scale vegetation history obtained from the adjacent large lake, Laguna Chaplin ( $\mathrm{LCH}$; Mayle et al., 2000; Burbridge et al., 2004). Our results from CV demonstrate that palm swamps in southern Amazonia have the potential to yield Pleistocene-age paleoecological records that provide information about vegetation on terra firme landscapes beyond the basin itself, rather than simply recording a history of wetland vegetation within the swamp. Comparison between the $\mathrm{CV}$ and $\mathrm{LCH}$ pollen records reveals both local- and regional-scale evidence for savannas during the LGM, and a savanna/SDTF mosaic during the middle Holocene. These results demonstrate that the paleoecological value of tropical palm swamps, such as CV, is considerably greater than often assumed - with the potential to yield local-scale, glacialinterglacial histories of climate-driven, terrestrial vegetation dynamics. Although a palm swamp today, the CV site was previously an open-water lake during the LGM, demonstrating that the pollen taphonomy and catchment of this basin has changed markedly through time. 
722 Due to its local-scale pollen catchment, and close proximity to the Río Paraguá, the CV pollen 723 record also reveals the history of riverine vegetation in ecotonal, southern Amazonia. We find 724 that drier climatic conditions of the LGM and middle Holocene supported expansion of open 725 savanna, not only in the interfluves, but in riverine areas too, challenging the common 726 assumption that rainforest persisted as refugia in ribbons of gallery rainforest lining the rivers. 727 The absence of significant gallery rainforest during past drier climatic conditions raises 728 concerns that gallery rainforest may not be resilient to projected future increased drought and 729 may therefore not be relied upon to serve as rainforest migration corridors, as has previously 730 been proposed (e.g. Mayle et al., 2007). 
732 Macarena Cárdenas and John Carson provided assistance with pollen sample processing and 733 pollen identification. RS was funded by a NERC 'SCENARIO' DTP PhD award (2014-18). 734 Funding for LOI analysis and 5 radiocarbon dates was provided by to S.Y.M. from the Global 735 Change and Sustainability Center, the Graduate Research Fellowship, and the Don Currey 736 Graduate Research Fellowship at the University of Utah. The further 4 dates were funded by 737 the School of Archaeology, Geography and Environment Science, University of Reading. We 738 thank Mary Mclntyre and Daniel Harris for their help in sample preparation and analysis. Tim 739 Killeen, Juan Surubi, Pastor Sollis, Rene Guillen, and the 'Museo de Historia Natural Noel

740 Kempff Mercado' provided logistical support to access and core the CV site. The University of 741 Leicester provided a start-up grant to FM (1995) to support the fieldwork. We thank Mark 742 Bush and an anonymous reviewer, whose comments improved the manuscript.

\section{REFERENCES}

Absy, M.L., Cleef, A., Fournier, M., Martin, L., Servant, M., Sifeddine, A., Ferreira da Silva, M., Soubiès, F., Suguio, K., Turcq, B., van der Hammen, T., 1991. Mize en évidence de quatre phases d'ouverture de la forêt dense dans le Sud-Est de l'Amazonie au cours des 60000 dernières années: première comparaison avec d'autres régions tropicales. Comptes rendus de I"Académie des sciences. Série 2, Mécanique, Physique, Chimie, Sciences de l"univers, Sciences de la Terre 312, 673-678.

Aragão, L.E.O.C., Anderson, L.O., Fonseca, M.G., Rosan, T.M., Vedovato, L.B., Wagner, 754 F.H., Silva, C.V.J., Junior, C.H.L.S., Arai, E., Aguiar, A.P., Barlow, J., Berenguer, E., Deeter, M.N., Domingues, L.G., Gatti, L., Gloor, M., Malhi, Y., Marengo, J.A., Miller, J.B., Phillips, O.L., Saatchi, S.S., 2018. 21st Century drought-related fires counteract the decline of Amazon deforestation carbon emissions. Nature communications 9, 1-12.

Aragão, L.E.O.C., Poulter, B., Barlow, J.B., Anderson, L.O., Malhi, Y., Saatchi, S.S., Phillips, O.L., Gloor, E., 2014. Environmental change and the carbon balance of Amazonian forests. Biological Reviews 89, 913-931. South America. Quaternary Science Reviews 124, 31-47. 
Baker, P.A., Seltzer, G.O., Fritz, S.C., Dunbar, R.B., Grove, M.J., Tapia, P.M., Cross, S.L., Rowe, H.D., Broda, J.P., 2001. The history of South American tropical precipitation for the past 25,000 years. Science 291, 640-643.

Barberi, M., Salgado-Labouriau, M.L., Suguio, K., 2000. Paleovegetation and paleoclimate of "Vereda de Águas Emendadas," central Brazil. Journal of South American Earth Sciences 13, 241-254.

Bartlein, P.J., Harrison, S.P., Brewer, S., Connor, S., Davis, B.A.S., Gajewski, K., Guiot, J., Harrison-Prentice, T.I., Henderson, A., Peyron, O., Prentice, I.C., Scholze, M., Seppä, H., Shuman, B., Sugita, S., Thompson, R.S., Viau, A.E., Williams, J., Wu, H., 2011. Pollen-based continental climate reconstructions at 6 and $21 \mathrm{ka}$ : a global synthesis. Climate Dynamics 37, 775-802.

Behling, H., Berrio, J.C., Hooghiemstra, H., 1999. Late Quaternary pollen records from the middle Caquetá river basin in central Colombian Amazon. Palaeogeography, Palaeoclimatology, Palaeoecology 145, 193-213.

Behling, H., Hooghiemstra, H., 1999. Environmental history of the Colombian savannas of the Llanos Orientales since the Last glacial maximum from lake records El Pinal and Carimagua. Journal of Paleolimnology 21, 461-476.

Bennett, K.D., 1996. Determination of the number of zones in a biostratigraphical sequence. New Phytologist 132, 155-170.

Berger, A., Loutre, M.F., 1991. Insolation values for the climate of the last 10 million years. Quaternary Science Reviews 10, 297-317.

Bernal, J.P., Cruz, F.W., Stríkis, N.M., Wang, X., Deininger, M., Catunda, M.C.A., OrtegaObregón, C., Cheng, H., Edwards, R.L., Auler, A.S., 2016. High-resolution Holocene South American monsoon history recorded by a speleothem from Botuverá Cave, Brazil. Earth and Planetary Science Letters 450, 186-196.

Blaauw, M., Christen, J.A., 2011. Flexible paleoclimate age-depth models using an autoregressive gamma process. Bayesian Analysis 6, 457-474. 
802 Blaauw, M., Christen, J.A., Bennett, K.D., Reimer, P.J., 2018. Double the dates and go for

803 Bayes - Impacts of model choice, dating density and quality on chronologies. Quaternary

804 Science Reviews 188, 58-66.

805

806 Boisier, J.P., Ciais, P., Ducharne, A., Guimberteau, M., 2015. Projected strengthening of 807 Amazonian dry season by constrained climate model simulations. Nature Climate Change 5, 808 656-660.

809

810 Braconnot, P., Harrison, S.P., Kageyama, M., Bartlein, P.J., Masson-Delmotte, V., Abe-Ouchi, 811 A., Otto-Bliesner, B., Zhao, Y., 2012. Evaluation of climate models using palaeoclimatic data.

812 Nature Climate Change 2, 417-424.

813

814 Bronk Ramsey, C., 1995. Radiocarbon Calibration and Analysis of Stratigraphy: The OxCal 815 Program. Radiocarbon 37, 425-430.

816

817 Bronk Ramsey, C., 2009. Dealing with Outliers and Offsets in Radiocarbon Dating.

818 Radiocarbon 51, 1023-1045.

819

820 Burbridge, R.E., Mayle, F.E., Killeen, T.J., 2004. Fifty-thousand-year vegetation and climate

821 history of Noel Kempff Mercado National Park, Bolivian Amazon. Quaternary Research 61,

822 215-230.

823

824 Burn, M.J., Mayle, F.E., 2008. Palynological differentiation between genera of the Moraceae 825 family and implications for Amazonian palaeoecology. Review of Palaeobotany and 826 Palynology 149, 187-201.

827

828 Burn, M.J., Mayle, F.E., Killeen, T.J., 2010. Pollen-based differentiation of Amazonian 829 rainforest communities and implications for lowland palaeoecology in tropical South America.

830 Palaeogeography, Palaeoclimatology, Palaeoecology 295, 1-18.

831

832 Bush, M.B., Rivera, R., 2001. Reproductive ecology and pollen representation among 833 neotropical trees. Global Ecology and Biogeography 10, 359-367.

834

835 Bush, M.B., Weng, C., 2007. Introducing a new (freeware) tool for palynology. Journal of 836 Biogeography 34, 377-380. 
838 Carson, J.F., Whitney, B.S., Mayle, F.E., Iriarte, J., Prümers, H., Soto, J.D., Watling, J., 2014.

839 Environmental impact of geometric earthwork construction in pre-Columbian Amazonia.

840 Proceedings of the National Academy of Sciences 111, 10497-10502.

842 Cheng, H., Sinha, A., Cruz, F.W., Wang, X., Edwards, R.L., d'Horta, F.M., Ribas, C.C., Vuille, 843 M., Stott, L.D., Auler, A.S., 2013. Climate change patterns in Amazonia and biodiversity. 844 Nature communications 4, 1411.

846 Christensen, J.H., Hewitson, B., Busuioc, A., Chen, A., Gao, X., Held, I., Jones, R., Kolli, R.K., 847 Kwon, W.T., Laprize, R., Magana Rueda, V., Mearns, L., Menendez, C.G., Raisanen, J., 848 Rinke, A., Sarr, A., Whetton, P., 2007. Regional climate projections. In: Climate Change 2007: 849 The Physical Science Basis. Contribution of Working Group I to the Fourth Assessment Report 850 of the Intergovernmental Panel on Climate Change. Cambridge University Press, Cambridge, 851 United Kingdom and New York, NY, USA.

852

853 Colinvaux, P.A., Miller, M.C., Liu, K.B., SteinitzKannan, M., Frost, I., 1985. Discovery of 854 Permanent Amazon Lakes and Hydraulic Disturbance in the Upper Amazon Basin. Nature $855313,42-45$.

856

857 Collinvaux, P.A., De Oliveira, P.E., Moreno Patiño, J.E., 1999. Amazon pollen manual and atlas/Manual e atlas palinologico da Amazônia. Harwood Academic Publishers, Amsterdam.

860 Costa, L.P., 2003. The historical bridge between the Amazon and the Atlantic Forest of Brazil: 861 a study of molecular phylogeography with small mammals. Journal of Biogeography 30, 71862 86.

864 Cruz, F.W., Burns, S.J., Karmann, I., Sharp, W.D., Vuille, M., Cardoso, A.O., Ferrari, J.A., 865 Dias, P.L.S., Viana, O., 2005. Insolation-driven changes in atmospheric circulation over the past 116,000 years in subtropical Brazil. Nature 434, 63-66. I., Auler, A.S., Nguyen, H., 2009. Orbitally driven east-west antiphasing of South American precipitation. Nature Geoscience 2, 210-214.

872 Davis, B.A.S., Brewer, S., Stevenson, A.C., Guiot, J., 2003. The temperature of Europe during 873 the Holocene reconstructed from pollen data. Quaternary Science Reviews 22, 1701-1716. 
875 Davis, M.B., 2000. Palynology after Y2K - Understanding the source area of pollen in sediments. Annual Review of Earth and Planetary Sciences 28, 1-18.

Dean, W.E., 1974. Determination of carbonate and organic matter in calcareous sediments and sedimentary rocks by loss on ignition; comparison with other methods. Journal of Sedimentary Research 44, 242-248.

Doughty, C.E., Metcalfe, D.B., Girardin, C.A.J., Amézquita, F.F., Cabrera, D.G., Huasco, 883 W.H., Silva-Espejo, J.E., Araujo-Murakami, A., da Costa, M.C., Rocha, W., Feldpausch, T.R., 884 Mendoza, A.L.M., da Costa, A.C.L., Meir, P., Phillips, O.L., Malhi, Y., 2015. Drought impact on forest carbon dynamics and fluxes in Amazonia. Nature 519, 78-82.

886

Faegri, K., Iversen, J., 1989. Textbook of pollen analysis. Wiley, Chichester.

Feldpausch, T.R., Phillips, O.L., Brienen, R.J.W., Gloor, E., Lloyd, J., Lopez-Gonzalez, G., A.S., Aragão, L.E.O.C., Arroyo, L., Aymard, G.A., Baker, T.R., Baraloto, C., Barroso, J., Bonal, D., Castro, W., Chama, V., Chave, J., Domingues, T.F., Fauset, S., Groot, N., Coronado, E.H., 893 Laurance, S.G.W., Laurance, W.F., Lewis, S.L., Licona, J.C., Marimon, B.S., Marimon-Junior, 894 B.H., Bautista, C.M., Neill, D.A., Oliveira, E.A., Santos, dos, C.O., Camacho, N.C.P., PardoMolina, G., Prieto, A., Quesada, C.A., Ramírez, F., Ramirez-Angulo, H., Réjou-Méchain, M., 896 Rudas, A., Saiz, G., Salomao, R.P., Silva-Espejo, J.E., Silveira, M., Steege, ter, H., Stropp, J., Terborgh, J., Thomas-Caesar, R., van der Heijden, G.M.F., Martínez, R.V., Vilanova, E., Vos, V., 2016. Amazon forest response to repeated droughts. Biogeosciences 30, 964-982.

Fontes, D., Cordeiro, R.C., Martins, G.S., Behling, H., Turcq, B., Sifeddine, A., Seoane, J.C.S., Moreira, L.S., Rodrigues, R.A., 2017. Paleoenvironmental dynamics in South Amazonia,

902 Brazil, during the last 35,000 years inferred from pollen and geochemical records of Lago do Saci. Quaternary Science Reviews 173, 161-180.

904

Gajewski, K., 2008. The Global Pollen Database in biogeographical and palaeoclimatic studies. Progress in Physical Geography 32, 379-402.

907

908 Gosling, W.D., Mayle, F.E., Tate, N.J., Killeen, T.J., 2005. Modern pollen-rain characteristics 909 of tall terra firme moist evergreen forest, southern Amazonia. Quaternary Research 64, 284297. 
912 Gosling, W.D., Mayle, F.E., Tate, N.J., Killeen, T.J., 2009. Differentiation between Neotropical

913 rainforest, dry forest, and savannah ecosystems by their modern pollen spectra and

914 implications for the fossil pollen record. Review of Palaeobotany and Palynology 153, 70-85.

915

916 Grimm, E.C., 1987. CONISS: a FORTRAN 77 program for stratigraphically constrained cluster

917 analysis by the method of incremental sum of squares. Computers \& Geosciences 13, 13-35.

918

919 Harrison, S.P., Prentice, I.C., 2003. Climate and CO2 controls on global vegetation distribution

920 at the last glacial maximum: analysis based on palaeovegetation data, biome modelling and

921 palaeoclimate simulations. Global Change Biology 9, 983-1004.

922

923 Haug, G.H., Hughen, K.A., Sigman, D.M., Peterson, L.C., Röhl, U., 2001. Southward migration

924 of the intertropical convergence zone through the Holocene. Science 293, 1304-1308.

925

926 Heiri, O., Lotter, A.F., Lemcke, G., 2001. Loss on ignition as a method for estimating organic 927 and carbonate content in sediments: reproducibility and comparability of results. Journal of 928 Paleolimnology 25, 101-110.

929

930 Hermanowski, B., da Costa, M.L., Behling, H., 2012. Environmental changes in southeastern

931 Amazonia during the last 25,000yr revealed from a paleoecological record. Quaternary

932 Research 77, 138-148.

933

934 Heyer, J.P., Power, M.J., Field, R.D., van Marle, M.J.E., 2018. The impacts of recent drought 935 on fire, forest loss, and regional smoke emissions in lowland Bolivia. Biogeosciences 15, 936 4317-4331.

937

938 Hogg, A.G., Hua, Q., Blackwell, P.G., Niu, M., Buck, C.E., 2013. SHCal13 Southern 939 Hemisphere calibration, 0-50,000 years cal BP. Radiocarbon 55, 1889-1903.

940

941 Indermühle, A., Stocker, T.F., Joos, F., Fischer, H., Smith, H.J., Wahlen, M., Deck, B., 942 Mastroianni, D., Tschumi, J., Blunier, T., Meyer, R., Stauffer, B., 1999. Holocene carbon-cycle 943 dynamics based on CO2 trapped in ice at Taylor Dome, Antarctica. Nature 398, 121-126.

944

945 Iriarte, J., Smith, R.J., Gregorio de Souza, J., Mayle, F.E., Whitney, B.S., Cárdenas, M.L., 946 Singarayer, J.S., Carson, J.F., Roy, S., Valdes, P., 2017. Out of Amazonia: Late-Holocene 947 climate change and the Tupi-Guarani trans-continental expansion. The Holocene 27, 967948975. 
950 Jacobson, G.L., Bradshaw, R.H.W., 1981. The Selection of Sites for Paleovegetational 951 Studies. Quaternary Research 16, 80-96.

952

953 Joetzjer, E., Douville, H., Delire, C., Ciais, P., 2013. Present-day and future Amazonian 954 precipitation in global climate models: CMIP5 versus CMIP3. Climate Dynamics 41, 29219552936.

956

957 Jones, H.T., Mayle, F.E., Pennington, R.T., Killeen, T.J., 2011. Characterisation of Bolivian 958 savanna ecosystems by their modern pollen rain and implications for fossil pollen records.

959 Review of Palaeobotany and Palynology 164, 223-237.

960

961 Juggins, S., 2017. rioja: analysis of quaternary science data. R package version 0.9-15.1. 962 http://cran.r-project.org/package=rioja.

963

964 Kanner, L.C., Burns, S.J., Cheng, H., Edwards, R.L., Vuille, M., 2013. High-resolution 965 variability of the South American summer monsoon over the last seven millennia: insights from 966 a speleothem record from the central Peruvian Andes. Quaternary Science Reviews 75, 196710.

968

969 Kelley, D.I., Prentice, I.C., Harrison, S.P., Wang, H., Simard, M., Fisher, J.B., Willis, K.O., 970 2013. A comprehensive benchmarking system for evaluating global vegetation models. 971 Biogeosciences 10, 3313-3340.

972

973 Killeen, T.J., Jardim, A., Mamani, F., Rojas, N., 1998. Diversity, composition and structure of 974 a tropical semideciduous forest in the Chiquitanía region of Santa Cruz, Bolivia. Journal of 975 Tropical Ecology 14, 803-827.

976

977 Killeen, T.J., Schulenberg, T.S. (eds), 1998. A biological assessment of Parque Nacional Noel 978 Kempff Mercado, Bolivia. Rapid Assessment Program Working Papers 10. Conservation 979 International, Washington, D.C., USA.

980

981 Killeen, T.J., Siles, T.M., Grimwood, T., Tieszen, L.L., Steininger, M.K., Tucker, C.J., Panfil, 982 S., 2003. Habitat heterogeneity on a forest-savanna ecotone in Noel Kempff Mercado National 983 Park (Santa Cruz, Bolivia): implications for the long-term conservation of biodiversity in a 984 changing climate. In: How Landscapes Change. Ecological Studies (Analysis and Synthesis). 985 Springer, pp. 285-312. 
987 Kohfeld, K.E., Harrison, S.P., 2000. How well can we simulate past climates? Evaluating the 988 models using global palaeoenvironmental datasets. Quaternary Science Reviews 19, 321346.

990

Latrubesse, E.M., 2012. Amazon Lakes. In: Encyclopedia of Lakes and Reservoirs. Springer,

992 pp. 13-26.

993

994

995

Ledru, M.-P., Bertaux, J., Sifeddine, A., Suguio, K., 1998. Absence of Last glacial maximum 996

Lorente, F.L., Buso Junior, A.A., De Oliveira, P.E., Pessenda, L.C.R., 2017. Atlas Palinológico. Laboratório C14 - CENA/USP. Fundação de Estudos Agrários Luiz de Queiroz (FEALQ), Piracicaba.

Maezumi, S.Y., Alves, D., Robinson, M., de Souza, J.G., Levis, C., Barnett, R.L., Almeida de Oliveira, E., Urrego, D., Schaan, D., Iriarte, J., 2018a. The legacy of 4,500 years of polyculture agroforestry in the eastern Amazon. Nature Plants 4, 540-547.

Maezumi, S.Y., Power, M.J., Mayle, F.E., McLauchlan, K.K., Iriarte, J., 2015. Effects of past climate variability on fire and vegetation in the cerrãdo savanna of the Huanchaca Mesetta, NE Bolivia. Climate of the Past 11, 835-853.

Maezumi, S.Y., Whitney, B.S., Mayle, F.E., de Souza, J.G., Iriarte, J., 2018b. Reassessing climate and pre-Columbian drivers of paleofire activity in the Bolivian Amazon. Quaternary International 488, 81-94.

1012

1013 Marchant, R., Cleef, A., Harrison, S.P., Hooghiemstra, H., Markgraf, V., van Boxel, J., Ager, 1014 T., Almeida, L., Anderson, R., Baied, C., Behling, H., Berrio, J.C., Burbridge, R.E., Björck, S., 1015 Byrne, R., Bush, M.B., Duivenvoorden, J., Flenley, J., De Oliveira, P.E., van Geel, B., Graf, 1016 K., Gosling, W.D., Harbele, S., van der Hammen, T., Hansen, B., Horn, S., Kuhry, P., Ledru, 1017 M.-P., Mayle, F.E., Leyden, B., Lozano-Garcia, S., Melief, A.M., Moreno Patiño, J.E., Moar, 1018 N.T., Prieto, A., van Reenen, G., Salgado-Labouriau, M.L., Schäbitz, F., Schreve-Brinkman, 1019 E.J., Wille, M., 2009. Pollen-based biome reconstructions for Latin America at 0, 6000 and 18 1020000 radiocarbon years ago. Climate of the Past 5, 725-767. 
1022 Mayle, F.E., Burbridge, R.E., Killeen, T.J., 2000. Millennial-scale dynamics of southern

1023 Amazonian rain forests. Science 290, 2291-2294.

1025 Mayle, F.E., Langstroth, R.P., Fisher, R.A., Meir, P., 2007. Long-term forest-savannah 1026 dynamics in the Bolivian Amazon: implications for conservation. Philosophical Transactions of the Royal Society B: Biological Sciences 362, 291-307.

McCormac, F.G., Hogg, A.G., Blackwell, P.G., Buck, C.E., 2004. SHCal04 Southern Hemisphere calibration, 0-11.0 cal kyr BP. Radiocarbon 46, 1087-1092.

Meave, J., Kellman, M., 1994. Maintenance of Rain-Forest Diversity in Riparian Forests of

1033 Tropical Savannas - Implications for Species Conservation During Pleistocene Drought.

1034 Journal of Biogeography 21, 121-135.

Meave, J., Kellman, M., MacDougall, A., Rosales, J., 1991. Riparian Habitats as Tropical Forest Refugia. Global Ecology and Biogeography Letters 1, 69-76.

Meneses, M.E.N.S., Costa, M.L., Enters, D., Behling, H., 2015. Environmental changes during the last millennium based on multi-proxy palaeoecological records in a savanna-forest mosaic from the northernmost Brazilian Amazon region. Anais da Academia Brasileira de Ciências 87, 1623-1651.

1044 Metcalfe, S.E., Whitney, B.S., Fitzpatrick, K.A., Mayle, F.E., Loader, N.J., Street-Perrott, F.A., 1045 Mann, D.G., 2014. Hydrology and climatology at Laguna La Gaiba, lowland Bolivia: complex responses to climatic forcings over the last 25000 years. Journal of Quaternary Science 29, 289-300.

1049 Monnin, E., Indermühle, A., Dällenbach, A., Flückiger, J., Stauffer, B., Stocker, T.F., Raynaud, 1050 D., Barnola, J.M., 2001. Atmospheric CO2 concentrations over the last glacial termination. 1051 Science 291, 112-114.

1053 Ni, J., Yu, G., Harrison, S.P., Prentice, I.C., 2010. Palaeovegetation in China during the late 1054 Quaternary: Biome reconstructions based on a global scheme of plant functional types. 
1057 Oksanen, J., Blanchet, F.G., Kindt, R., Legendre, P., Minchin, P.R., O’hara, R.B., Simpson, 1058 G.L., Solymos, P., Stevens, M.H.H., Wagner, H., others, 2018. vegan: Community Ecology 1059 Package. R package version 2.4-6. https://CRAN.R-project.org/package=vegan.

1060

1061 Pan, Y., Birdsey, R.A., Fang, J., Houghton, R., Kauppi, P.E., Kurz, W.A., Phillips, O.L., 1062 Shvidenko, A., Lewis, S.L., Canadell, J.G., Ciais, P., Jackson, R.B., Pacala, S.W., McGuire, 1063 A.D., Piao, S., Rautiainen, A., Sitch, S., Hayes, D., 2011. A large and persistent carbon sink 1064 in the world's forests. Science 333, 988-993.

1065

1066 Pennington, R.T., Prado, D.E., Pendry, C.A., 2000. Neotropical seasonally dry forests and 1067 Quaternary vegetation changes. Journal of Biogeography 27, 261-273.

1068

1069 Phillips, O.L., Aragão, L.E.O.C., Lewis, S.L., Fisher, J.B., Lloyd, J., Lopez-Gonzalez, G., Malhi, 1070 Y., Monteagudo, A., Peacock, J., Quesada, C.A., van der Heijden, G.M.F., Almeida, S., 1071 Amaral, I., Arroyo, L., Aymard, G., Baker, T.R., Banki, O., Blanc, L., Bonal, D., Brando, P.M., 1072 Chave, J., de Oliveira, A.C.A., Cardozo, N.D., Czimczik, C.I., Feldpausch, T.R., Freitas, M.A., 1073 Gloor, E., Higuchi, N., Jimenez, E., Lloyd, G., Meir, P., Mendoza, C., Morel, A., Neill, D.A., 1074 Nepstad, D., Patino, S., Penuela, M.C., Prieto, A., Ramírez, F., Schwarz, M., Silva, J., Silveira, 1075 M., Thomas, A.S., Steege, ter, H., Stropp, J., Vasquez, R., Zelazowski, P., Davila, E.A., 1076 Andelman, S., Andrade, A.S., Chao, K.J., Erwin, T., Di Fiore, A., Coronado, E.N.H., Keeling, 1077 H., Killeen, T.J., Laurance, W.F., Cruz, A.P., Pitman, N.C.A., Vargas, P.N., Ramirez-Angulo, 1078 H., Rudas, A., Salamao, R., Silva, N., Terborgh, J., Torres-Lezama, A., 2009. Drought Sensitivity of the Amazon Rainforest. Science 323, 1344-1347.

Prentice, I.C., Bartlein, P.J., Webb, T., 1993. Vegetation and Climate Change in Eastern North America Since the Last glacial maximum. Ecology 74, 998-998.

1083

1084

Raia, A., Cavalcanti, I.F.A., 2008. The Life Cycle of the South American Monsoon System. 1086

1087 Redford, K.H., da Fonseca, G.A.B., 1986. The Role of Gallery Forests in the Zoogeography of the Cerrado's Non-volant Mammalian Fauna. Biotropica 18, 126.

Reimer, P.J., Bard, E., Bayliss, A., Beck, J.W., Blackwell, P.G., Bronk Ramsey, C., Buck, C.E., Cheng, H., Edwards, R.L., Friedrich, M., Grootes, P.M., Guilderson, T.P., Haflidason, H., Hajdas, I., Hatté, C., Heaton, T.J., Hoffmann, D.L., Hogg, A.G., Hughen, K.A., Kaizer, K.F., Kromer, B., Manning, S.W., Niu, M., Reimer, R.W., Richards, D.A., Scott, E.M., Southon, J.R., 
1094 Staff, R.A., Turney, C.S.M., van der Plicht, J., 2013. IntCal13 and Marine13 Radiocarbon Age

1095 Calibration Curves 0-50,000 Years cal BP. Radiocarbon 55, 1869-1887.

1096

1097 Reis, L.S., Guimarães, J.T.F., Souza-Filho, P.W.M., Sahoo, P.K., de Figueiredo, M.M.J.C., de 1098 Souza, E.B., Giannini, T.C., 2017. Environmental and vegetation changes in southeastern 1099 Amazonia during the late Pleistocene and Holocene. Quaternary International 449, 83-105.

Roberts, N., Fyfe, R.M., Woodbridge, J., Gaillard, M.J., Davis, B.A.S., Kaplan, J.O., Marquer, L., Mazier, F., Nielsen, A.B., Sugita, S., Trondman, A.-K., Leydet, M., 2018. Europe's lost forests: a pollen-based synthesis for the last 11,000 years. Scientific Reports $8,1-8$.

Rodríguez-Zorro, P.A., 2017. Mid-Holocene vegetation dynamics with an early expansion of Mauritia flexuosa palm trees inferred from the Serra do Tepequém in the savannas of Roraima State in Amazonia, northwestern Brazil. Vegetation History and Archaeobotany 26, 455-468.

1109 Rodríguez-Zorro, P.A., Enters, D., Hermanowski, B., da Costa, M.L., Behling, H., 2015. 1110 Vegetation changes and human impact inferred from an oxbow lake in southwestern 1111 Amazonia, Brazil since the 19th century. Journal of South American Earth Sciences 62, 186194.

1114 Roubik, D.W., Moreno Patiño, J.E., 1991. Pollen and spores of Barro Colorado Island.

1115 Monographs in Systematic Botany, v. 36. Missouri Botanical Garden, St Louis, MO.

1117 Roucoux, K.H., Lawson, I.T., Jones, T.D., Baker, T.R., Coronado, E.N.H., Gosling, W.D., 1118 Lähteenoja, O., 2013. Vegetation development in an Amazonian peatland. Palaeogeography, 1119 Palaeoclimatology, Palaeoecology 374, 242-255.

1121 Sawada, M., Viau, A.E., Vettoretti, G., Peltier, W.R., Gajewski, K., 2004. Comparison of North1122 American pollen-based temperature and global lake-status with CCCma AGCM2 output at 1123 6ka. Quaternary Science Reviews 23, 225-244.

1125 Seltzer, G.O., Rodbell, D.T., Baker, P.A., Fritz, S.C., Tapia, P.M., Rowe, H.D., Dunbar, R.B., 1126 2002. Early warming of tropical South America at the last glacial-interglacial transition. 1127 Science 296, 1685-1686. 
1129 Sifeddine, A., Martin, L., Turcq, B., Volkmer-Ribeiro, C., Soubiès, F., Cordeiro, R.C., Suguio, 1130 K., 2001. Variations of the Amazonian rainforest environment: a sedimentological record 1131 covering 30,000 years. Palaeogeography, Palaeoclimatology, Palaeoecology 168, 221-235.

1133 Silva, L., Sternberg, L., Haridasan, M., 2008. Expansion of gallery forests into central Brazilian savannas. Global Change Biology 14, 2108-2118.

Silva, V.B.S., Kousky, V.E., 2012. The South American Monsoon System: Climatology and Variability. In: Wang, S., Gillies, R.R. (Eds.), Modern Climatology. pp. 123-152.

Smith, R.J., Mayle, F.E., 2018. Impact of mid- to late Holocene precipitation changes on vegetation across lowland tropical South America: a paleo-data synthesis. Quaternary Research 89, 134-155.

1143 Stockmarr, J., 1971. Tablets with Spores used in Absolute Pollen Analysis. Pollen et Spores 1144 13, 615-621.

Stute, M., Forster, M., Frischkorn, H., Serejo, A., Clark, J.F., Schlosser, P., Broecker, W.S., Bonani, G., 1995. Cooling of Tropical Brazil $\left(5^{\circ} \mathrm{C}\right)$ During the Last glacial maximum. Science 269, 379-383.

Sugita, S., 1994. Pollen Representation of Vegetation in Quaternary Sediments - Theory and Method in Patchy Vegetation. Journal of Ecology 82, 881-897.

Sugita, S., 2007a. Theory of quantitative reconstruction of vegetation I: pollen from large sites REVEALS regional vegetation composition. The Holocene 17, 229-241.

Sugita, S., 2007b. Theory of quantitative reconstruction of vegetation II: all you need is LOVE. The Holocene 17, 243-257.

Sugita, S., Gaillard, M.J., Broström, A., 1999. Landscape openness and pollen records: a simulation approach. The Holocene 9, 409-421.

1162 Thompson, L.G., Davis, M., Mosley-Thompson, E., Sowers, T., Henderson, K., Zagorodnov, 1163 V.S., Lin, P., Mikhalenko, V., Campen, R., Bolzan, J., Cole-Dai, J., Francou, B., 1998. A 1164 25,000-year tropical climate history from Bolivian ice cores. Science 282, 1858-1864. 
1166 Tian, F., Cao, X., Dallmeyer, A., Zhao, Y., Ni, J., Herzschuh, U., 2017. Pollen-climate 1167 relationships in time ( $9 \mathrm{ka}, 6 \mathrm{ka}, 0 \mathrm{ka}$ ) and space (upland vs. lowland) in eastern continental 1168 Asia. Quaternary Science Reviews 156, 1-11.

Toivonen, T., Mäki, S., Kalliola, R., 2007. The riverscape of Western Amazonia - a quantitative approach to the fluvial biogeography of the region. Journal of Biogeography 34, 1374-1387.

Twiddle, C.L., Bunting, M.J., 2010. Experimental investigations into the preservation of pollen grains: A pilot study of four pollen types. Review of Palaeobotany and Palynology 162, 621630.

van Breukelen, M.R., Vonhof, H.B., Hellstrom, J.C., Wester, W.C.G., Kroon, D., 2008. Fossil dripwater in stalagmites reveals Holocene temperature and rainfall variation in Amazonia. Earth and Planetary Science Letters 275, 54-60.

Viau, A.E., Gajewski, K., Sawada, M.C., Fines, P., 2006. Millennial-scale temperature variations in North America during the Holocene. Journal of Geophysical Research 111, 48312.

Wang, X., Auler, A.S., Edwards, R.L., Cheng, H., Ito, E., Wang, Y., Kong, X., Solheid, M., 2007. Millennial-scale precipitation changes in southern Brazil over the past 90,000 years. Geophysical Research Letters 34, L23701.

Whitney, B.S., Mayle, F.E., 2012. Pediastrum species as potential indicators of lake-level change in tropical South America. Journal of Paleolimnology 47, 601-615.

Whitney, B.S., Mayle, F.E., Punyasena, S.W., Fitzpatrick, K.A., Burn, M.J., Guillen, R., 1193 Chavez, E., Mann, D., Pennington, R.T., Metcalfe, S.E., 2011. A 45 kyr palaeoclimate record 1194 from the lowland interior of tropical South America. Palaeogeography, Palaeoclimatology, Palaeoecology 307, 177-192.

Wright, H.E., 1967. A square-rod piston sampler for lake sediments. Journal of Sedimentary Research 37, 975-976. Wu, H., Guiot, J., Brewer, S., Guo, Z., 2007. Climatic changes in Eurasia and Africa at the last glacial maximum and mid-Holocene: reconstruction from pollen data using inverse vegetation modelling. Climate Dynamics 29, 211-229. 
1204 Zhou, J., Lau, K.M., 1998. Does a monsoon climate exist over South America? Journal of 1205 Climate 11, 1020-1040.

1206

1207 


\section{LIST OF TABLES}

1209 Table 1 - List of the accelerator mass spectrometry radiocarbon dates from the Cuatro 1210 Vientos sediment core.

1211

1212 Table 2 - List of the accelerator mass spectrometry radiocarbon dates from the Laguna

1213 Chaplin sediment core, taken from Burbridge et al. (2004). 


\section{LIST OF FIGURES}

1215 Figure 1 - Map of Noel Kempff Mercado National Park (NKMNP), showing modern-day

1216 vegetation distribution and the location of sites referred to in the text: Cuatro Vientos (CV),

1217 Laguna Chaplin (LCH), Laguna Bella Vista (LBV) and Laguna La Gaiba (LLG)

1218

1219 Figure 2 - Google Earth image of the Cuatro Vientos (CV) palm swamp and Laguna

1220 Chaplin ( $\mathrm{LCH}$ ) in relation to the Rio Paragua. The dotted lines depict the Rio Paragua, the

1221 perimeters of the CV and LCH basins, and the margin between the seasonally-flooded

1222 riverine rainforest and the inter-fluvial terra firme (non-flooded) rainforest. The red dots

1223 show the coring locations of the two sites. The photo shows Mauritiella palm and the

1224 floating sedge/grass mat in the CV palm swamp.

1226 Figure 3 - Radiocarbon dates, age-depth model and lithological description for Cuatro

1227 Vientos

1229 Figure 4 - Pollen percentage diagram of taxa from Cuatro Vientos, plotted against

1230 calibrated years BP. Dots signify $<1 \%$ abundance. $5 x$ exaggeration is shown for rare taxa.

1232 Figure 5 - Pollen percentage diagram of taxa from Laguna Chaplin, plotted against

1233 calibrated years BP. Dots signify $<1 \%$ abundance. Zonations are based on the pollen zones

1234 of Cuatro Vientos to aid in comparison.

1236 Figure 6 - Summary percentage diagrams for (a) Cuatro Vientos and (b) Laguna Chaplin,

1237 for the time period covered by the Cuatro Vientos record (ca. 24,000-3750 cal yr BP).

1238 Groupings as in Figs. 4 and 5: Humid Evergreen Tropical Forest (HETF), Semi-deciduous

1239 Tropical Forest (SDTF), Savanna (SAV), Palm trees (PALM), Cold Adapted Taxa (CAT),

1240 Herbs, weeds and shrubs (HERB), Aquatic/Semi-Aquatic (AQ). 

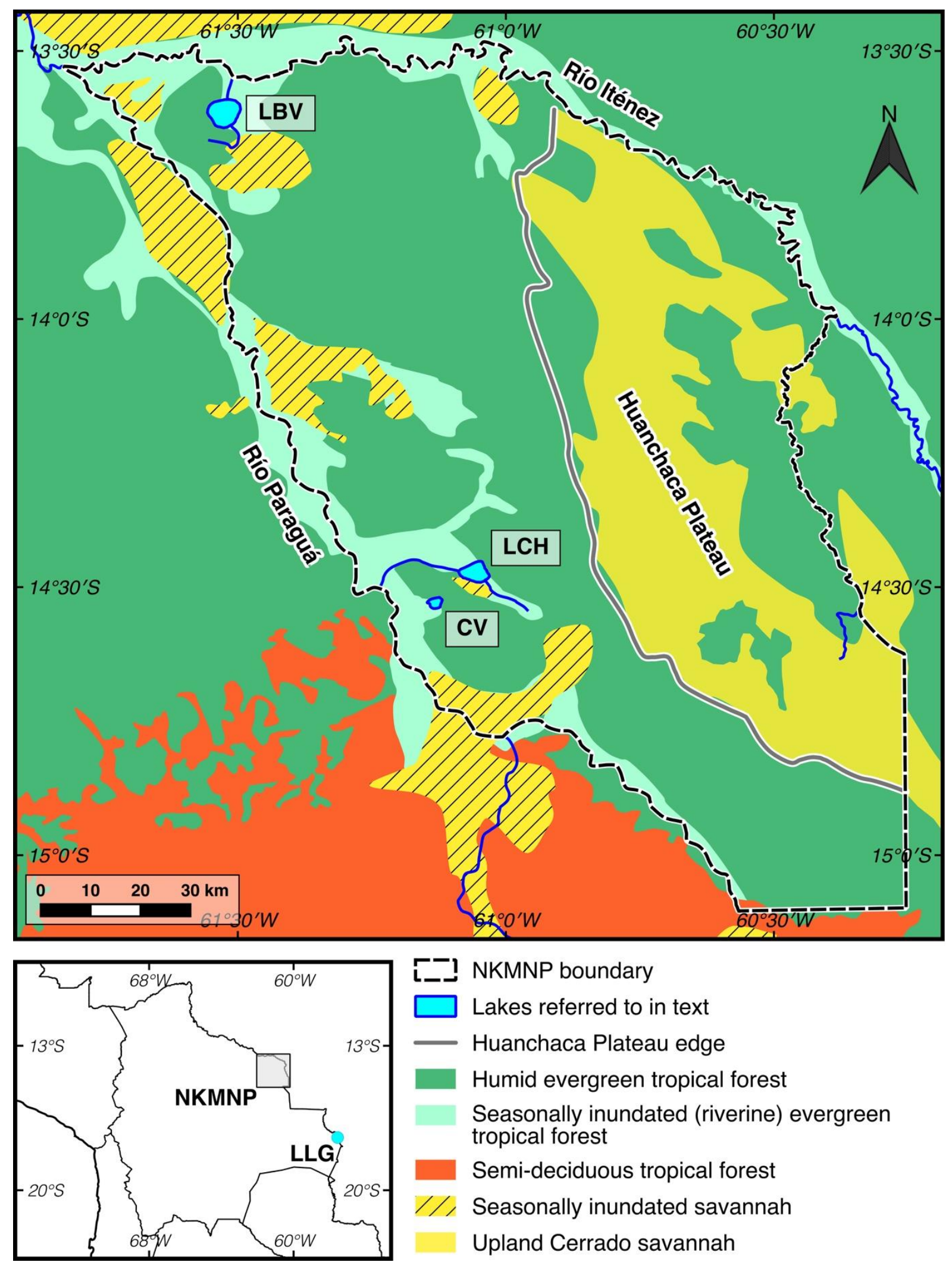

[-] NKMNP boundary

$\square$ Lakes referred to in text

_ Huanchaca Plateau edge

Humid evergreen tropical forest

Seasonally inundated (riverine) evergreen tropical forest

Semi-deciduous tropical forest

Seasonally inundated savannah

Upland Cerrado savannah 


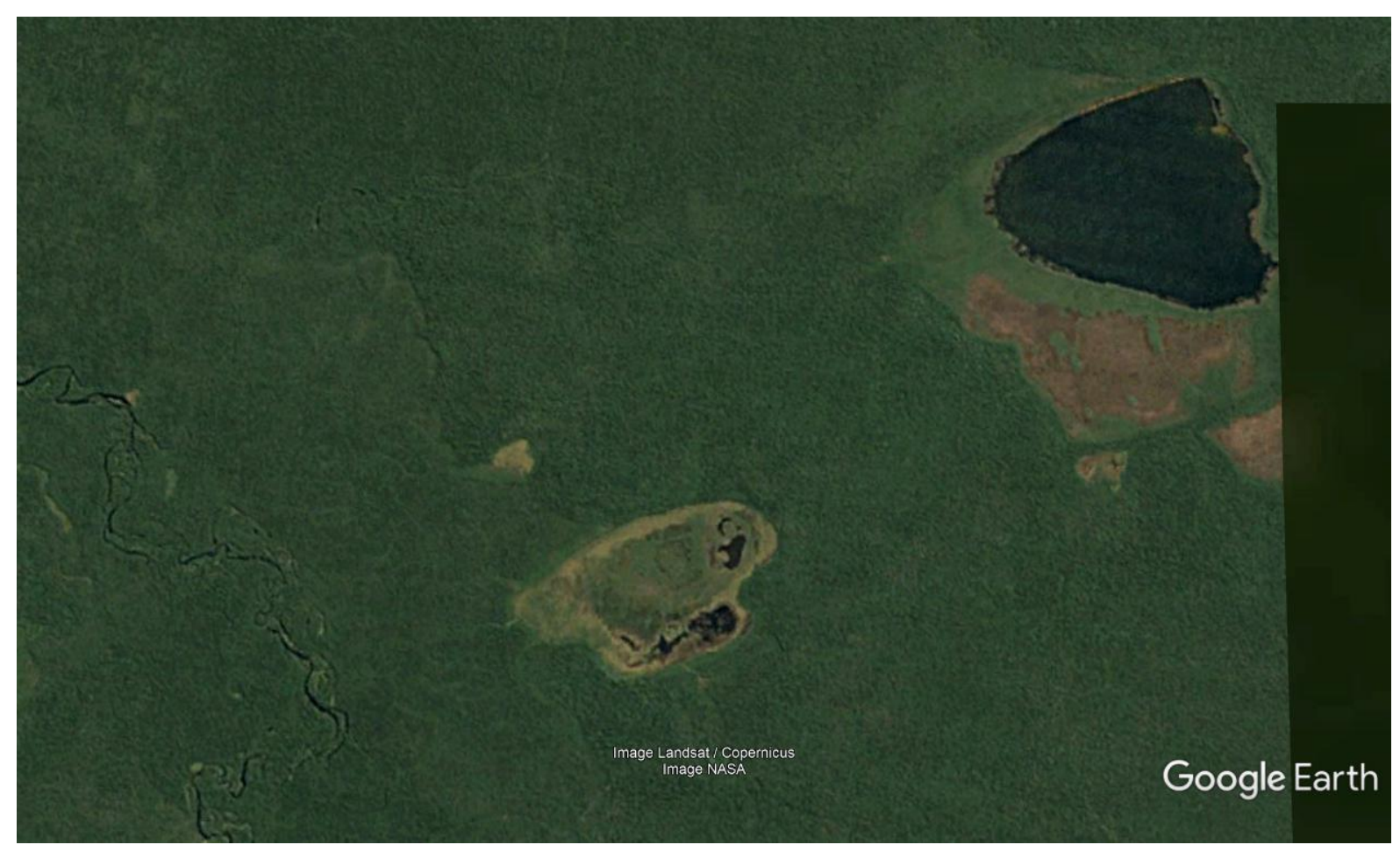

Figure 2

1251

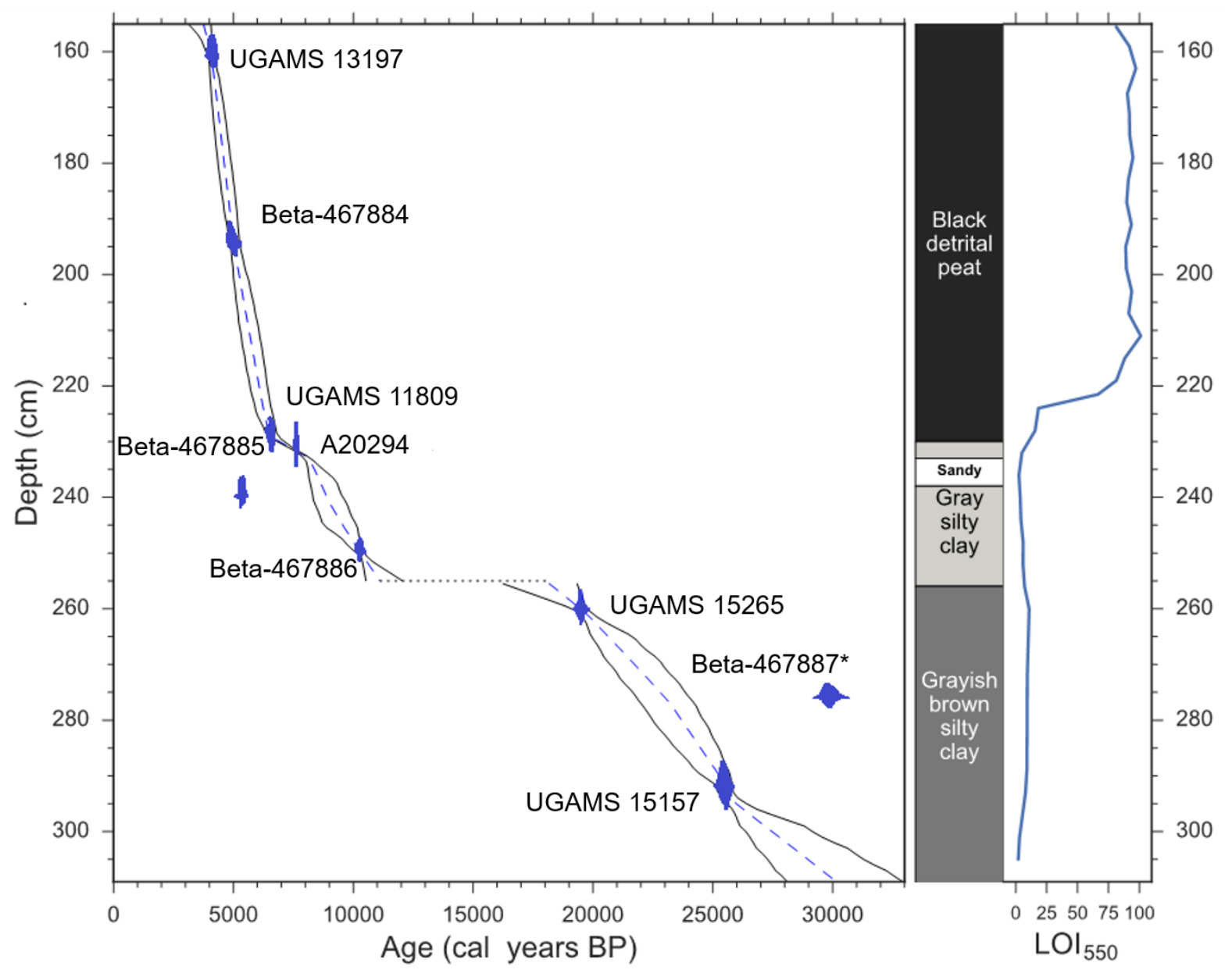




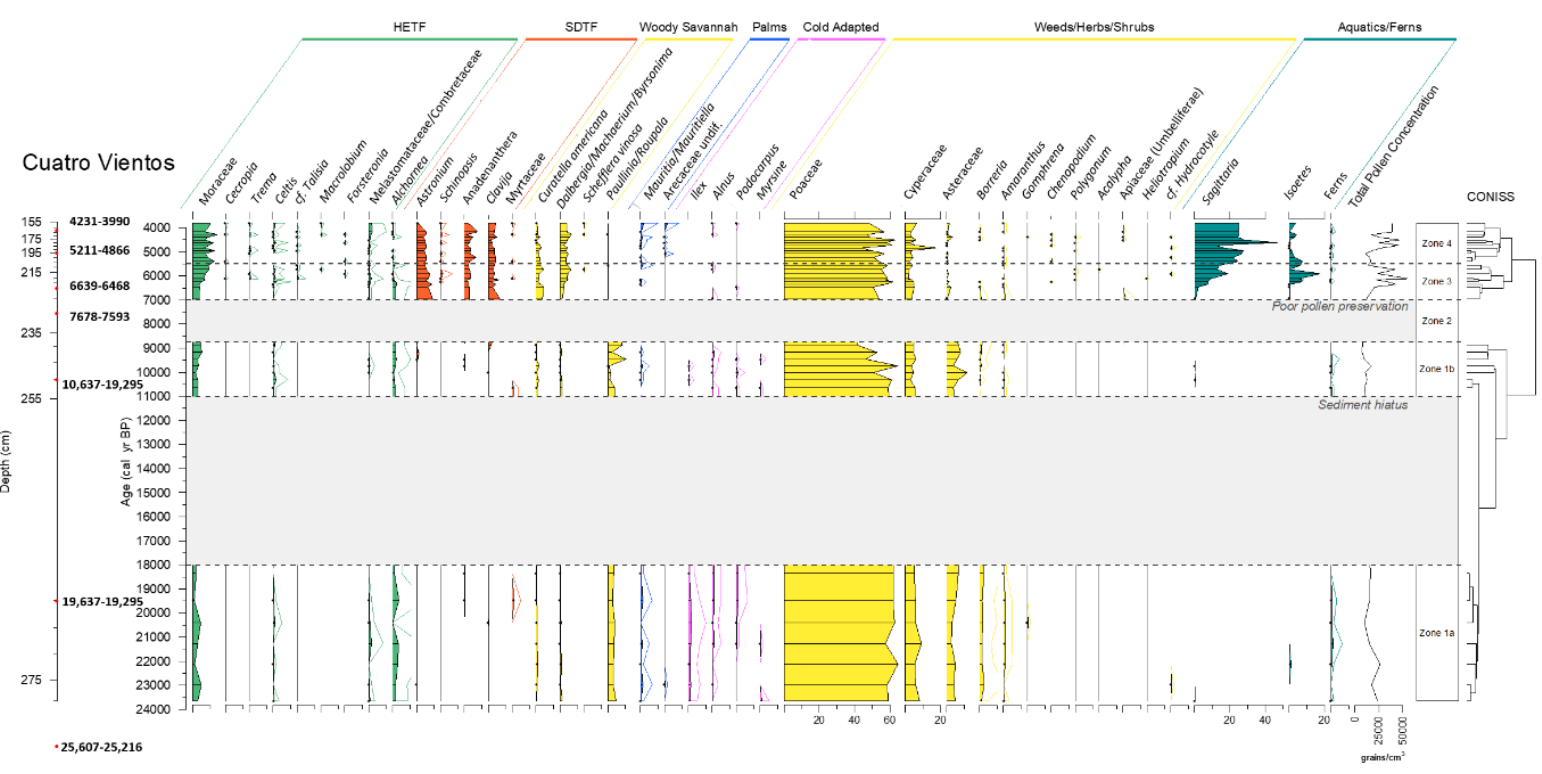

1255

1256

Figure 4

1257

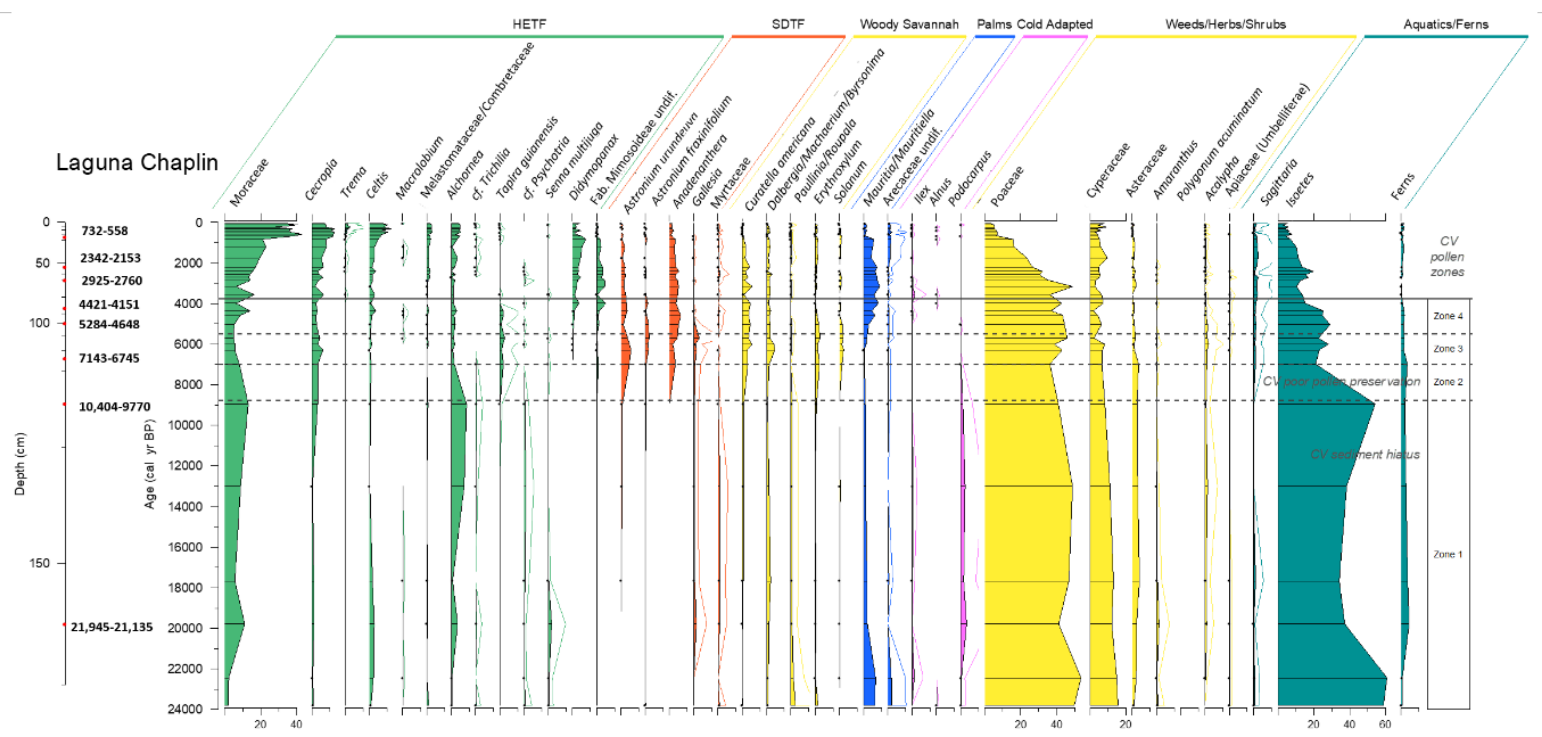

1258

1259 Figure 5

1260 


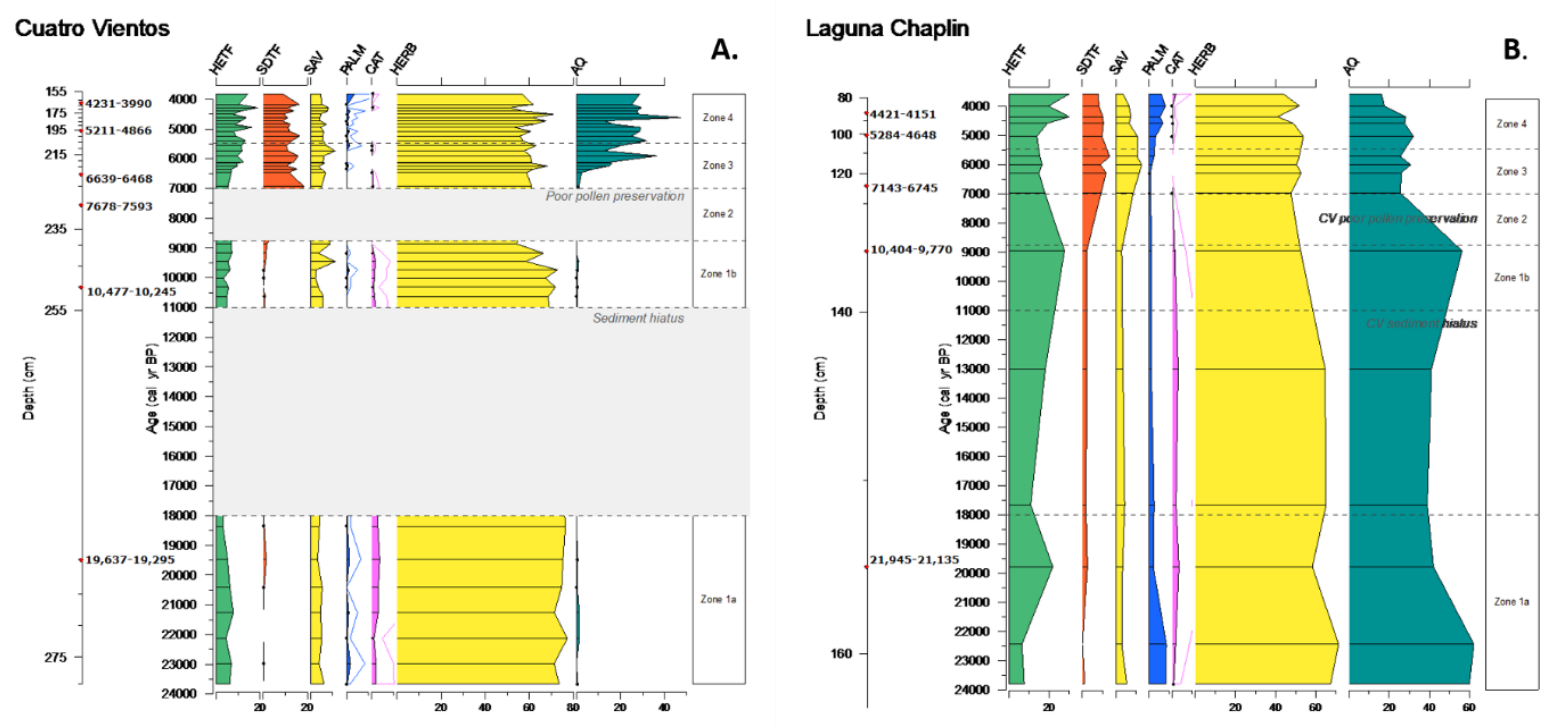

1263 Figure 6

1264

1265 Table 1 - List of the accelerator mass spectrometry radiocarbon dates from the Cuatro

1266 Vientos sediment core

\begin{tabular}{lllll}
\hline Laboratory code & $\begin{array}{l}\text { Sample } \\
\text { depth } \\
\text { (cm below } \\
\text { FMV) }\end{array}$ & Dated material & $\begin{array}{l}\text { AMS }{ }^{14} \mathbf{C} \text { age } \\
\text { (yr BP } \pm \mathbf{1} \text { ) })\end{array}$ & $\begin{array}{l}\text { Calibrated age range } \\
\text { (cal yr BP) } \pm \mathbf{2} \text { }\end{array}$ \\
\hline UGAMS 13197 & 161.5 & Bulk sediment & $3760 \pm 25$ & $4231-3990$ \\
Beta-467884 & 195 & Plant remains & $4400 \pm 30$ & $5211-4866$ \\
UGAMS 11809 & 229 & Bulk sediment & $5750 \pm 30$ & $6639-6468$ \\
A20294 & 231.5 & Bulk sediment & $6800 \pm 26$ & $7678-7593$ \\
Beta-467885* & 240 & Plant remains & $4640 \pm 30$ & $5465-5307$ \\
Beta-467886 & 250 & Bulk sediment & $9180 \pm 30$ & $10,477-10,245$ \\
UGAMS 15265 & 260 & Bulk sediment & $16,140 \pm 40$ & $19,637-19,295$ \\
Beta-467887* & 276 & Bulk sediment & $25,700 \pm 90$ & $30,276-29,502$ \\
UGAMS 15157 & 292 & Bulk sediment & $21,070 \pm 50$ & $25,607-25,216$
\end{tabular}

${ }^{*}$ dates not included in age-depth model

1270 Table 2 - List of the accelerator mass spectrometry radiocarbon dates from the Laguna

1271 Chaplin sediment core, taken from Burbridge et al. (2004) 


\begin{tabular}{lllll}
\hline Laboratory code & $\begin{array}{l}\text { Sample } \\
\text { depth } \\
(\mathbf{c m})\end{array}$ & Dated material & $\begin{array}{l}\text { AMS }{ }^{14} \mathbf{C} \text { age } \\
(\mathbf{y r ~ B P} \pm \mathbf{1 \sigma})\end{array}$ & $\begin{array}{l}\text { Calibrated age range } \\
\text { (cal. yr BP) } \pm \mathbf{~} \boldsymbol{\sigma}\end{array}$ \\
\hline Beta-137570 & 36.5 & Bulk sediment & $710 \pm 50$ & $732-558$ \\
AA39700 & 51.5 & Bulk sediment & $2240 \pm 40$ & $2342-2153$ \\
AA39701 & 69.5 & Bulk sediment & $2740 \pm 40$ & $2925-2760$ \\
AA39702 & 85 & Bulk sediment & $3870 \pm 50$ & $4421-4151$ \\
AA39703 & 100 & Bulk sediment & $4330 \pm 80$ & $5284-4648$ \\
AA39704 & 125 & Bulk sediment & $6040 \pm 50$ & $7143-6745$ \\
AA39705 & 135 & Bulk sediment & $9000 \pm 100$ & $10404-9770$ \\
AA39706 & 155 & Bulk sediment & $17820 \pm 140$ & $21945-21135$ \\
AA39707 & 175 & Bulk sediment & $31060 \pm 440$ & $35941-34190$ \\
AA39708 & 195 & Bulk sediment & $34820 \pm 700$ & $41160-37945$ \\
AA39709 & 213 & Bulk sediment & $37750 \pm 970$ & $43801-40455$ \\
AA39710* & 250 & Bulk sediment & $43400 \pm 1900$ & - \\
AA39711* & 285 & Bulk sediment & $41200 \pm 1400$ & - \\
AA39712* & 296 & Bulk sediment & $38100 \pm 1000$ & - \\
\hline
\end{tabular}

*dates not included in age-depth model 